\title{
DNA Repair Syndromes and Cancer: Insights Into Genetics and Phenotype Patterns
}

\author{
Richa Sharma ${ }^{1,2}$, Sara Lewis ${ }^{1}$ and Marcin W. Wlodarski ${ }^{1,3 *}$ \\ 'Department of Hematology, St. Jude Children's Research Hospital, Memphis, TN, United States, ${ }^{2}$ Department of Oncology, \\ St. Jude Children's Research Hospital, Memphis, TN, United States, ${ }^{3}$ Division of Pediatric Hematology and Oncology, \\ Department of Pediatrics and Adolescent Medicine, Medical Center, Faculty of Medicine, University of Freiburg, Freiburg, \\ Germany
}

DNA damage response is essential to human physiology. A broad spectrum of pathologies are displayed by individuals carrying monoallelic or biallelic loss-of-function mutations in DNA damage repair genes. DNA repair syndromes with biallelic disturbance of essential DNA damage response pathways manifest early in life with multi-systemic involvement and a high propensity for hematologic and solid cancers, as well

\section{OPEN ACCESS}

Edited by:

Riccardo Masetti,

University of Bologna, Italy

Reviewed by:

Jean Soulier,

Hôpital Saint-Louis, France

Rachel E. Rau,

Baylor College of Medicine

United States

Huiming Lu,

University of Texas Southwestern

Medical Center, United States

*Correspondence:

Marcin W. Wlodarski

marcin.wlodarski@stjude.org

Specialty section:

This article was submitted to Pediatric Oncology,

a section of the journal

Frontiers in Pediatrics

Received: 06 June 2020 Accepted: 18 September 2020

Published: 23 October 2020

Citation:

Sharma $R$, Lewis $S$ and Wlodarski MW (2020) DNA Repair Syndromes and Cancer: Insights Into Genetics and Phenotype Patterns.

Front. Pediatr. 8:570084.

doi: 10.3389/fped.2020.570084 as bone marrow failure. In this review, we describe classic biallelic DNA repair cancer syndromes arising from faulty single- and double-strand DNA break repair, as well as dysfunctional DNA helicases. These clinical entities include xeroderma pigmentosum, constitutional mismatch repair deficiency, ataxia telangiectasia, Nijmegen breakage syndrome, deficiencies of DNA ligase IV, NHEJ/Cernunnos, and ERCC6L2, as well as Bloom, Werner, and Rothmund-Thompson syndromes. To give an in-depth understanding of these disorders, we provide historical overview and discuss the interplay between complex biology and heterogeneous clinical manifestations.

Keywords: DNA repair, cancer predisposition, hematological malignances, hereditary cancer, pediatric cancer

\section{INTRODUCTION}

Preservation of genomic DNA is fundamental to maintenance of life. Mammalian DNA can withstand at least $10^{5}$ lesions in a single cell per day caused by intrinsic biological processes and extrinsic genotoxic agents (1). DNA repair mechanisms are highly complex and conserved pathways that have evolved over time. Their role is to restore genomic damage so that naturally occurring DNA lesions are rapidly neutralized and transmission of accurate genetic code across generations can occur (2). In this review, we discuss biological and clinical features of classic DNA repair disorders that predispose to hematologic and solid cancers early in life. Due to intricate genetic underpinnings and heterogeneous clinical manifestations, the diagnosis of these underappreciated syndromes is challenging and typically requires a high index of suspicion. Insight into specific phenotype spectrum and associated cancers can increase awareness of these rare syndromes. As a result, a timely diagnosis and multidisciplinary management with focus on structured surveillance can improve life expectancy in this pediatric population.

Sources of DNA damage are constant, innumerable, and divided into endogenous and exogenous culprits. Endogenous damage is caused by replication errors, as well as reactive intermediates secondary to essential cellular chemical reactions (reactive oxygen species, aldehydes). Exogenous damaging agents include ultraviolet (UV) and ionizing 
radiation, environmental chemicals (polycyclic aromatic hydrocarbons, benzo[a]pyrene, aromatic compounds), and chemotherapeutic agents including DNA-alkylators (temozolomide), DNA crosslinkers (mitomycin C or cisplatin), topoisomerase inhibitors (etoposide), and radiomimetics (bleomycin) (2-4). These often unavoidable insults cause toxic DNA intermediates such as single-nucleotide lesions, helical distorting adducts and dimers, single-strand breaks (SSBs), and double-stranded breaks (DSBs), all of which activate the DNA damage response (Figure 1) (5).

The DNA damage response is a molecular surveillance system that regulates cell cycle progression at G1-S, intra-S, and G2-M checkpoints to maintain genomic stability (6). Heritable genetic mutations in this safeguard infrastructure results in cancer predisposition syndromes (5). Li-Fraumeni syndrome (LFS) is the prototypical cancer susceptibility disorder characterized by early onset of solid and hematological cancers due to germline monoallelic mutations in p53, a tumor suppressor gene (7) [excellent reviews can be found elsewhere (8)]. LFS highlights the central role of p53 as a bona fide genome guardian, which modulates G1-S and G2-M checkpoints in response to DNA damage pathways $(9,10)$. At least eight DNA repair mechanisms have been described to orchestrate the repair of mammalian DNA in a cooperative and redundant fashion (2). Importantly, nucleotide excision repair (NER), mismatch repair (MMR), homologous recombination (HR), non-homologous end joining (NHEJ), and inter-strand DNA crosslink repair have been associated with Mendelian syndromes with cancer predisposition in children (Figure 1, Table 1).

Although classic DNA repair syndromes affect pediatric population, their rarity, complex genetics, and heterogeneous phenotypic features make them underrecognized. In the following, we highlight other (non-FA) DNA repair pathway deficiencies and the resulting clinical manifestations in hopes of minimizing missed opportunities for early diagnosis and riskadapted treatment of aggressive cancers that increase morbidity and mortality in this biologically distinct patient population.

\section{SYNDROMES CAUSED BY FAULTY SINGLE STRAND BREAK REPAIR}

SSBs are the most common type of DNA lesion that represent discontinuity in one of the two strands of the DNA helix (11). Single-strand lesions induce replication block and can progress to lethal DSBs if unrepaired in active replicating cells (12) while causing cell death in post-mitotic cells $(13,14)$. Three repair mechanisms, BER, MMR, and NER, have evolved to mitigate single-strand breaks. BER ameliorates single base damage [detailed review available (15)], which when abrogated can lead to colorectal cancers in adults $(16,17)$ without evidence to cause childhood cancers. In contrast, both MMR, which resolves base mismatch and insertions-deletions (indels), and NER, which resolves bulky helix distorting lesions, are associated with pediatric cancer predisposition syndromes (Figure 1).

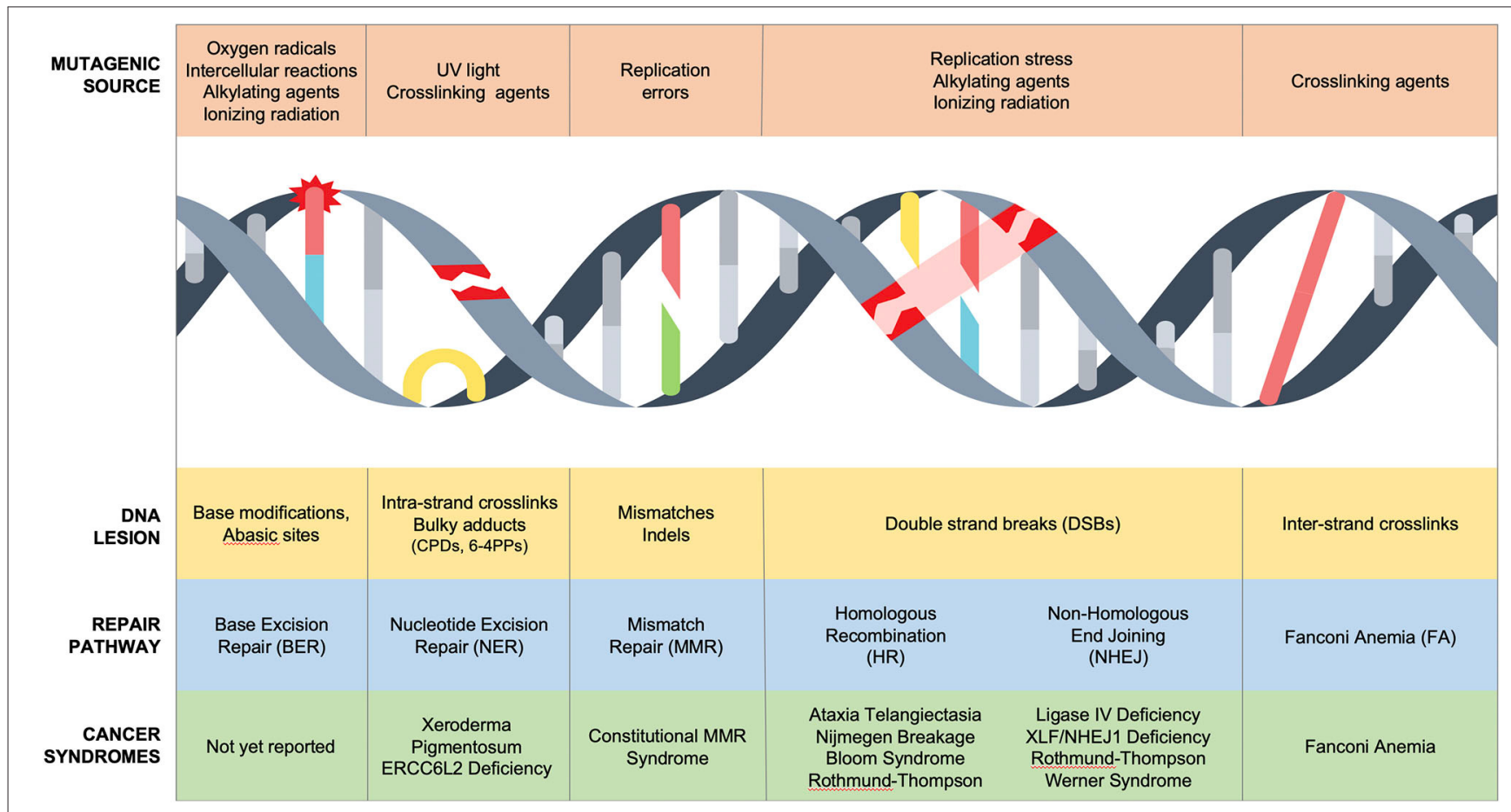

FIGURE 1 | DNA repair disorders associated with cancer predisposition in pediatric population. Several DNA damage sources cause unique DNA lesions that are repaired by specific DNA repair pathways. Biallelic mutations in NER, MMR, HR, NHEJ, and FA/HR cause cancer predisposition syndromes of childhood. 
TABLE 1 | DNA repair deficiencies in single strand and double strand DNA repair and RECQ helicases result in classic DNA repair syndromes with multisystemic manifestations and oncogenic predisposition.

\begin{tabular}{|c|c|c|c|c|c|}
\hline DNA repair pathway & $\begin{array}{l}\text { Associated } \\
\text { syndrome }\end{array}$ & $\begin{array}{l}\text { Expected biallelic } \\
\text { mutations }\end{array}$ & Clinical testing & Clinical features & $\begin{array}{l}\text { Malignancy } \\
\text { spectrum }\end{array}$ \\
\hline \multicolumn{6}{|c|}{ SINGLE STRAND BREAK REPAIR DISORDERS } \\
\hline \multirow[t]{2}{*}{ NER } & $\begin{array}{l}\text { Xeroderma } \\
\text { Pigmentosum }\end{array}$ & $\begin{array}{l}X P A, X P B, X P C, X P D \\
X P E, X P F, X P G, X P V\end{array}$ & $\begin{array}{l}\text { Screening: UV } \\
\text { hypersensitivity } \\
\text { Confirmation: } \\
\text { genetic testing }\end{array}$ & $\begin{array}{l}\text { Skin } \\
\text { Ocular } \\
\text { Neurologic }\end{array}$ & $\begin{array}{l}\text { Major: SCC, BCC, } \\
\text { melanoma } \\
\text { Minor: AML/MDS, } \\
\text { brain/spinal cord }\end{array}$ \\
\hline & ERCC6L2 deficiency & ERCC6L2 & Genetic testing & $\begin{array}{l}\text { Neurologic } \\
\text { Bone marrow failure }\end{array}$ & MDS, erythroleukemia \\
\hline MMR & $\begin{array}{l}\text { Constitutional } \\
\text { mismatch repair } \\
\text { disorder }\end{array}$ & $\begin{array}{l}\text { MLH1, MSH2, MSH6, } \\
\text { PMS2 }\end{array}$ & $\begin{array}{l}\text { Screening: IHC, MSI, } \\
\text { hypermutation } \\
\text { (>100/MB) } \\
\text { Confirmation: } \\
\text { genetic testing }\end{array}$ & Skin & $\begin{array}{l}\text { Major: brain, Gl, T-NHL, } \\
\text { ALL, AML } \\
\text { Minor: sarcomas, GU }\end{array}$ \\
\hline \multicolumn{6}{|c|}{ DOUBLE STRAND BREAK REPAIR DISORDERS } \\
\hline \multirow[t]{2}{*}{$\mathrm{HR}$} & Ataxia telangiectasia & ATM & $\begin{array}{l}\text { Screening: TREC, AFP, } \\
\text { telomere length, t(7;14) } \\
\text { Confirmation: } \\
\text { Genetic testing }\end{array}$ & $\begin{array}{l}\text { Neurologic } \\
\text { Immunologic } \\
\text { Endocrine }\end{array}$ & $\begin{array}{l}\text { Major: B-NHL, HL, } \\
\text { ALL, breast } \\
\text { Minor: gastric, brain }\end{array}$ \\
\hline & $\begin{array}{l}\text { Nijmegen breakage } \\
\text { syndrome }\end{array}$ & $N B N$ & $\begin{array}{l}\text { Screening: TREC, AFP, } \\
\text { telomere length, t(7;14) } \\
\text { Confirmation: } \\
\text { Genetic testing }\end{array}$ & $\begin{array}{l}\text { Neurologic } \\
\text { Endocrine } \\
\text { Immunologic }\end{array}$ & $\begin{array}{l}\text { Major: B-NHL, T-LBL } \\
\text { Minor: HL, ALL, AML, } \\
\text { brain tumors, sarcoma }\end{array}$ \\
\hline NHEJ & $\begin{array}{l}\text { DNA Ligase IV } \\
\text { Deficiency syndrome }\end{array}$ & LIG4 & $\begin{array}{l}\text { Screening: TREC } \\
\text { Confirmation: } \\
\text { Genetic testing }\end{array}$ & $\begin{array}{l}\text { Endocrine } \\
\text { Immunologic } \\
\text { Bone marrow failure }\end{array}$ & $\begin{array}{l}\text { Major: ALL, B-NHL } \\
\text { Minor: AML, MDS }\end{array}$ \\
\hline FA & Fanconi anemia & 22 FA genes ${ }^{\star}$ & $\begin{array}{l}\text { Screening: } \\
\text { Chromosomal } \\
\text { breakage, AFP, } \\
\text { telomere length } \\
\text { Confirmation: } \\
\text { Genetic testing }\end{array}$ & $\begin{array}{l}\text { Congenital anomalies } \\
\text { Bone marrow failure } \\
\text { Endocrine }\end{array}$ & $\begin{array}{l}\text { Major: SCC } \\
\text { (head/neck), AML, } \\
\text { MDS } \\
\text { Minor: anogenital }\end{array}$ \\
\hline \multicolumn{6}{|c|}{ RECQ HELICASE DEFICIENT REPAIR DISORDERS } \\
\hline $\mathrm{HR}$ & Bloom syndrome & $B L M$ & $\begin{array}{l}\text { Screening: SCEs, } \\
\text { telomere length } \\
\text { Confirmation: } \\
\text { Genetic testing }\end{array}$ & $\begin{array}{l}\text { Endocrine } \\
\text { Skin } \\
\text { Immunologic }\end{array}$ & $\begin{array}{l}\text { Major: AML, ALL, } \\
\text { B-NHL, colorectal } \\
\text { Minor: breast, SCC, } \\
\text { BCC, Wilm's }\end{array}$ \\
\hline \multirow[t]{4}{*}{ HR, NHEJ } & Werner syndrome & WRN & $\begin{array}{l}\text { Screening: telomere } \\
\text { length } \\
\text { Confirmation: } \\
\text { Genetic testing }\end{array}$ & $\begin{array}{l}\text { Aging, premature } \\
\text { Heart } \\
\text { Endocrine }\end{array}$ & $\begin{array}{l}\text { Major: thyroid follicular } \\
\text { carcinoma } \\
\text { Minor: melanoma, } \\
\text { sarcomas, MDS, AML }\end{array}$ \\
\hline & $\begin{array}{l}\text { Rothmund-thompson } \\
\text { syndrome }\end{array}$ & RECQL4 & $\begin{array}{l}\text { Confirmation: Genetic } \\
\text { testing }\end{array}$ & $\begin{array}{l}\text { Skin } \\
\text { Ocular }\end{array}$ & $\begin{array}{l}\text { Major: Osteosarcoma, } \\
\text { BCC, SCC, melanoma } \\
\text { Minor: AML, } \\
\text { MDS, Iymphoma }\end{array}$ \\
\hline & Rapadilino & & & $\begin{array}{l}\text { Endocrine } \\
\text { Skeletal anomalies }\end{array}$ & $\begin{array}{l}\text { Major: Iymphoma**, } \\
\text { osteosarcoma }\end{array}$ \\
\hline & Baller-gerold syndrome & & & Skeletal anomalies & NK/T cell lymphoma \\
\hline
\end{tabular}

\#Cockayne syndrome and Trichothiodystrophy are important NER deficient syndromes that do not exhibit cancer predisposition risk.

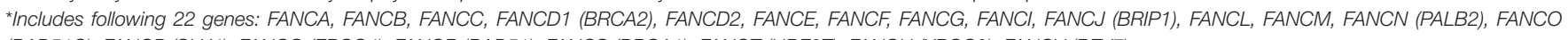
(RAD51C), FANCP (SLX4), FANCQ (ERCC4), FANCR (RAD51), FANCS (BRCA1), FANCT (UBE2T), FANCU (XRCC2), FANCV (REV7).

${ }^{\star *}=$ types of lymphomas not reported in literature.

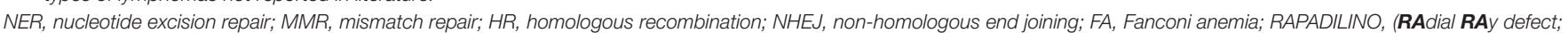

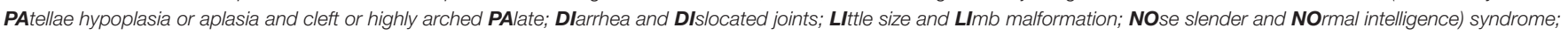
XPA-G, xeroderma pigmentosum A-G; XPV, xeroderma pigmentosum V; MLH1, MutL homolog 1; MSH2, MutS homolog. 2; MSH6, MutS homolog 6; PMS2, PMS1 homolog 2; ATM, Ataxia telangiectasia mutated; NBN, Nibrin; LIG4, DNA ligase 4; BLM, Bloom syndrome RecQ like helicase; WRN, Werner syndrome RecQ like helicase; RECQL4, REQ like helicase 4; UV, ultra-violet; IHC, immunohistochemistry; MSI, microsatellite instability; TREC, T cell receptor excision circles; AFP, Alpha-fetoprotein; SCEs, sister chromatid exchanges; SCC, squamous cell carcinoma; BCC, basal cell carcinoma; Gl, gastrointestinal; GU, genitourinary; ALL, acute lymphoblastic leukemia; AML, acute myeloid leukemia; MDS, myelodysplastic syndrome; NHL, non-Hodgkin lymphoma; HL, Hodgkin lymphoma; LBL, lymphoblastic lymphoma. 


\section{Xeroderma Pigmentosum (XP)}

$\mathrm{XP}$, the first DNA repair disorder described in 1874 by Hebra and Kaposi (18), is an autosomal recessive syndrome with dermatological, ocular, and neurological manifestations with skin cancer predisposition (Table 1). XP is estimated to affect 1 per million in the United States and 2.3 cases per million in Western Europe $(19,20)$ with higher prevalence in Japan (21) and North Africa (22). XP patients are unable to repair UV radiation-induced DNA damage due to mutations in the NER pathway. Biallelic mutations in one of the eight XP genes $[X P A-G$ and $X P$-variant $(V)]$ of the NER pathway cause classic $\mathrm{XP}$ (23). Mutations in XPA through XPG account for about $80 \%$ of XP cases with the remaining attributed to XPV (24). Patients commonly present by 2 years of age with increased number of lentigines (freckle-like pigmentation) in sun-exposed areas, a diagnostic skin finding in XP. Extreme sensitivity to sunlight resulting in acute severe sunburns is the presenting feature in $50 \%$ of patients. Increased sun exposure and lack of sun protection correlates with development of telangiectasias, pigmented seborrheic warty lesions, and atrophic skin $(20,25)$. Patients with mutations in $X P A, X P B, X P D, X P F$, and $X P G$ have severe photosensitivity at a young age (26). Photophobia is often present with ocular abnormalities limited to UV-exposed areas including eyelids, cornea, and conjunctiva (27). XPC patients are specifically hypersensitive to ocular damage with severe keratitis, corneal opacification, and vascularization (24). Approximately one third of patients exhibit progressive neuronal degeneration with $X P A, D$, and $G$ groups considered to be the most severely affected (28). Clinical presentations can be as subtle as loss of deep tendon reflexes and high-frequency sensorineural hearing to intellectual disability, motor dysfunction (spasticity, ataxia, difficulties swallowing), and frank quadriparesis $(25,26,29,30)$.

XP patients have an estimated 10,000-fold greater risk of developing basal cell and invasive squamous cell carcinomas compared to the general population, with median onset age of $<10$ years (29). The risk of melanoma has been estimated to be 2,000-fold higher, with median age of onset of 20 years (29). Interestingly, $X P C, X P E$, and $X P V$ mutations, which are classified as mild XP group due to only minor photosensitivity without neurological abnormalities, show the highest penetrance for cancers $(24,28)$. This is thought to be due to rapid accumulation of UV damage without sun protection in this patient population who lack overt skin findings resulting in late diagnosis (24). Mucosal cancers of the tongue, myelodysplastic syndrome (MDS), acute myeloid leukemia (AML), and tumors of the brain and spinal cord have also been described in XP patients (20, 24, 29, 31-33). Importantly, TP53 somatic alterations are exceptionally common in XP-associated skin tumors and MDS/AML with high rate of del5q and del7q karyotype alterations in XP-C patients $(33,34)$. The broad phenotype spectrum seen in XP is a direct consequence of NER deficits at the molecular level. The NER pathway is orchestrated by 30 proteins, and two subbranches, namely, global genomic repair and transcription-coupled repair, recognize and remove UV-induced cyclobutene pyrimidine dimers (CPD) and 6-4 pyrimidineprimidone (6-4PPs) dimers. Global genomic repair relies on XPC and XPE to sense DNA adducts while transcription-coupled repair recognizes damage on the transcribed strand using NER proteins: Cockayne syndrome A and B (CSA, CSB). Both subpathways converge to recruit XPD and XPB helicase-containing transcription complex to unwind damaged DNA. This allows XPA to secure single-strand DNA followed by incision of damaged DNA portion by endonucleases XPF/ERCC1 and XPG and gap filling by replication polymerases $(35,36)$. XPV/POLH is involved in replicating past unrepaired UV-induced thymine dimers or AP sites during translesion synthesis $(37,38)$. Of note, Cockayne syndrome (39) and Trichothiodystrophy (40) are important NER-deficient syndromes that do not exhibit cancer predisposition risk.

\section{ERCC Excision Repair 6 Like 2 (ERCC6L2) Deficiency}

Biallelic loss-of-function mutations in ERCC6 like 2 (ERCC6L2) have been associated with BMF, MDS, and acute erythroid leukemia (AML M6). ERCC6L2 is a Snf2 helicase that belongs to SWI/SNF protein family, which makes chromatin accessible to transcription machinery (41). Along with its role in RNA processing, ERCC6L2 plays a role in DNA repair by facilitating cross talk between transcription-coupled NER and NHEJ DNA repair pathways. Specifically, ERCC6L2 repairs transcriptionaffiliated DNA lesions through its interaction with DNA-PK (42), a central component of the NHEJ DNA repair complex (43). The first report linked homozygous truncating ERCC6L2 mutations to a bone marrow failure (BMF) syndrome manifesting with neurological and developmental findings in three index cases (9, 12, and 19 years of age) from consanguineous families (44). In another study, 7 patients, with median age of 13 years, were described to have hypocellular marrow in the setting of biallelic ERCC6L2 mutations, 2 of which displayed dysplastic marrow features with monosomy 7 (45). Of note, only 1 patient from a consanguineous family had neurological and developmental delays. Most recently, biallelic germline mutations were identified in five patients with the unique phenotype of acute erythroleukemia with median age of onset at 49 years. Additionally, all ERCC6L2-mutated acute erythroleukemia cases harbored somatic TP53 mutations at diagnosis (46). It remains to be answered if ERCC6L2 also plays a role in solid tumor predisposition and other types of hematologic malignancies.

\section{Constitutional Mismatch Repair Deficiency (CMMRD)}

CMMRD is a recessively inherited, cancer predisposition syndrome, which was described initially in 1999 (47, 48) and affects 1 in 1 million children (49). CMMRD is characterized by childhood onset of broad-spectrum malignancies secondary to biallelic (homozygous or compound heterozygous) germline mutations in the MMR pathway genes, mutL homolog 1 (MLH1), mutS homolog 2 (MSH2), mutS homolog 6 (MSH6), and PMS1 homology 2 (PMS2) (50, 51). Parental consanguinity enriching for a founder mutation is observed in over $50 \%$ of CMMRD cancers $(52,53)$. However, in Western countries, 
genotypes with compound heterozygous mutations among nonconsanguineous families are more common (54). In adults, monoallelic (heterozygous) mutations in these MMR genes are known to cause Lynch syndrome (LS), with predisposition primarily to colorectal, and endometrial cancers $(55,56)$.

The biological relevance of the MMR pathway is underscored in CMMRD patient tumors, which have a hypermutator phenotype (defined as $>10$ mutations/Mb), as a result of the inability for MMR machinery to identify and excise DNA damage. Specifically, MSH2-MSH6 heterodimer recognizes base-base mismatch and $\mathrm{MSH} 2-\mathrm{MSH} 3$ heterodimer detects large indel mismatch followed by mismatch excision by MLH1PMS2 (50). Abrogation of the essential MMR genes leaves behind a trail of incorrect base incorporation and indels, especially in microsatellite regions resulting in increased mutational burden and microsatellite instability, diagnostic hallmarks of CMMRD tumors. Finally, gap filling is accomplished by DNA polymerases epsilon (POLE) and delta (POLD1), which can acquire somatic mutations during tumorigenesis resulting in "ultra-hypermutated" (>100 mutations/Mb) CMMRD tumors (57, 58). POLE/POLD1 deficiency has been considered as a cancer susceptibility syndrome since mutation carriers with colonic and extra-colonic tumors have been reported (59-62). Importantly, childhood colorectal carcinoma and medulloblastoma in the setting of biallelic POLE mutations have been described $(63,64)$. Of note, heterozygous germline deletion of EPCAM, which causes epigenetic silencing of MSH2, thereby conferring an increased risk of colorectal cancer (65), in addition to biallelic mutation of $\mathrm{MSH}$, resulting in colorectal cancer (66), has expanded the spectrum of MMR deficient malignancies in humans.

CMMRD patients develop devastating malignancies at an early age with a median onset of 7.5 years (53). The cancer spectrum includes CNS tumors (estimated prevalence of 50\%), digestive tract tumors (40\%), hematological malignancies (33\%), and other solid cancers (67). In a cohort study with 31 patients, the median age at diagnosis of hematologic malignancies, brain tumors, and gastrointestinal cancers was 6.6, 10.3, and 16 years, respectively (54). Commonly encountered brain tumors are high-grade gliomas with few reports of lowgrade gliomas, CNS embryonal tumors, and medulloblastoma (49, 68, 69). Prevalent hematological malignancies are nonHodgkin lymphoma (NHL), particularly T-lymphoblastic NHL followed by $\mathrm{T}$ cell-acute lymphoblastic leukemia (T-ALL) and AML (49, 53, 70). The affected MMR gene correlates with the cancer spectrum. MSH6 and/or PMS2 biallelic mutations "favor" brain tumors while MLH1 or MSH2 mutations are biased for development of aggressive hematological malignancies $(53,68)$. Greater than $40 \%$ of PMS2-mutated patients develop secondary neoplasms. However, MLH1/MSH2 patients have a secondary malignancy risk of $22 \%$ due to poor survival from the first malignancy $(53,68)$. Expectedly, colorectal carcinoma, the most prevalent Lynch syndrome associated cancer, has higher prevalence in CMMRD patients with biallelic MSH6 or PMS2 mutations $(49,53)$. Other solid tumors include osteosarcoma, rhabdomyosarcoma, neuroblastoma, and Wilms tumor (53).
Outside of cancers, certain features are recurrently found in patients with CMMRD. Many patients present with dermatological manifestations such as café-au-lait macules (CALMs), hyper- and hypopigmented skin alterations, venous anomalies, and pilomatricomas (benign hair follicle tumor). At least one CALM or hyperpigmented skin area is found in more than $60 \%$ of patients (53). Agenesis of the corpus callosum and mild immunodeficiency with decreased levels of immunoglobulins IgG and IgA were previously described (53). Collectively, oncologic and non-oncologic clinical criteria are used in a three-point scoring system established by the European consortium "Care for CMMRD" (C4CMMRD) for diagnosis of CMMRD (53).

\section{SYNDROMES CAUSED BY FAULTY DOUBLE-STRANDED BREAK REPAIR}

DSBs are the most destructive DNA lesions, which, when left unattended, result in cell death. HR and NHEJ are the two main DSB DNA repair pathways that differ in key aspects. HR is a high-fidelity repair pathway that dominates during $S$ and G2 phase to repair DSB damage and relies on the presence of sister chromatids (71). In addition, it regulates essential cellular processes like meiotic recombination (72). On the other hand, an error-prone NHEJ pathway is active throughout the cell cycle (dominating in G1) and directly ligates two broken ends of a DSB. Outside of DNA repair, it is involved in T-cell receptor and immunoglobulin repertoire generation (73). The ability to resolve high-stake DSBs in a time-sensitive manner makes NHEJ a ubiquitous DSB repair pathway (74).

Since its first description by the Swiss pediatrician Guido Fanconi (75), Fanconi Anemia (FA) has been used as the prototypical example of a DSB repair syndrome associated with cancer. FA pathway recognizes and repairs toxic DNA interstrand crosslinks that induce a replication block followed by formation and repair of DSBs. The inability to resolve these crosslinks results in FA, a cancer predisposition syndrome caused by biallelic mutations in 1 of 22 FA genes (76-81). FA usually manifests early in life with congenital anomalies involving many organ systems, progressive BMF and a very high risk for the development of MDS, AML, head and neck carcinomas, as well as multiple other cancer types. A number of comprehensive studies and reviews on FA and FA-associated cancers have been published elsewhere (82-85).

We will review defects in the DNA repair machinery proteins of the HR system (ATM, NBN) and the NHEJ pathway (LIG4, NHEJ1, Artemis) that result in rare cancer predisposition disorders that exhibit radiosensitivity with overlapping clinical features including neurological deficits, cellular immunodeficiency with reduction or loss of $\mathrm{T}$ - and B-cells, hypogammaglobulinemia, and lymphoid cancers.

\section{Ataxia-Telangiectasia (AT)}

AT is an autosomal recessive disorder with an incidence of 1 per 40,000-100,000 births worldwide, initially described in 1941 by Louis-Bar but coined by Boer and Sedgwick in 1957 (86, 87). 
AT is a multisystemic disease characterized by ataxia secondary to cerebellar degeneration, telangiectasias, immunodeficiency with recurrent pulmonary infections, premature aging, ionizing radiation sensitivity, and a high risk of developing cancers of lymphoid origin (88). AT is a result of biallelic mutations of Ataxia Telangiectasia Mutated (ATM) (89), a PI3K-related serine/threonine protein kinase located on chromosome 11q22.3 (90), with a chief function to maintain genomic integrity. Following damage by ionizing radiation, chemotherapy, and oxidative stress (91), DSBs are recognized by MRN complex (MRE11-RAD50-NBS1), which activates ATM (92). Activated ATM amplifies DNA damage signaling by phosphorylating several downstream effectors including cell cycle proteins (Chk1, Chk2) (93), DNA repair proteins (BRCA1) (94), apoptosis (TP53) pathway, and other collaborative DNA damage nodes, including DNA-dependent protein kinase and ATM-related (ATR) $(95,96)$. Most ATM mutations are truncating and associated with severe or classic phenotype of AT due to a lack of functional kinase. Missense and in-frame mutations allow for some residual ATM activity and are associated with milder clinical course and slow progression $(97,98)$.

AT classically presents in early childhood, between 1 and 4 years of age, with ataxia manifesting as abnormal gait pattern in a child with otherwise previously normal development. Common neurological symptoms include dysarthria, impaired oculomotor coordination, loss of fine motor skills, and development of sensory and motor neuropathy along with extrapyramidal symptoms. Most patients become wheelchair-bound by the second decade of life (99-102). Telangiectasias are the second most common feature with average onset at 5-8 years of life and occur generally within the bulbar conjunctiva but can also appear on sun-exposed areas such as face and ears (103). Ocular telangiectasias should be differentiated from physiologic ocular vessels due to their constant presence without changing with environment or time. Immunodeficiency is another pronounced feature in two thirds of AT patients, which is demonstrated by a lack of antibody response to vaccines, reduced $\mathrm{B}$ and $\mathrm{T}$ cell numbers, and decreased production of at least one immunoglobulin subclass (IgG, IgA, and IgM) (104-106). Of note, a minority of AT patients have elevated IgM concurrently with IgA or IgG deficiency, so care must be taken to not misdiagnose these patients as hyperIgM syndrome (107). Sinopulmonary infections and increased risk of autoimmune or inflammatory diseases, such as ITP, cutaneous granulomatous disease, and vitiligo, is a direct result of immunodeficiency and immune dysregulation $(106,108$, 109). Endocrine abnormalities including poor growth, gonadal atrophy, delayed pubertal development, and insulin-resistant diabetes are also common (110-112).

AT patients have a $25 \%$ lifetime risk of developing a malignancy, which is the main cause of death in the second or third decade of life along with respiratory insufficiency (113115). The vast majority of these cancers are of lymphoid origin with B-cell NHL, Hodgkin lymphoma (HL), and ALL occurring at a higher rate in AT patients $<20$ years of age $(113,114)$. Strikingly, EBV infection was found to be associated with all $\mathrm{HL}$ and half of NHL cases. Other carcinomas including brain, gastric, and liver cancers have been reported $(113,114)$. Although previously debated, breast cancer is now considered as part of the cancer spectrum with a 30 -fold increased risk in AT patients (113). It has been postulated that cancer risk correlates with gene dosage, where patients with classic AT and lack of ATM kinase function are at higher risk of developing lymphoid tumors than patients with some residual AT activity (113).

\section{Nijmegen Breakage Syndrome (NBS)}

NBS is an autosomal recessive disease caused by biallelic mutations in $N B N$ located at $8 \mathrm{q} 21.3$. NBN gene codes for nibrin, which is one of three proteins that make up the MRN complex to activate and recruit ATM to DSBs (116). NBS was named after the Dutch city, Nijmegen, where it was first described in 1981 by Wermaes et al. (117). The prevalence is estimated to be 1 in 100,000 worldwide except in Central and Eastern European Slavic populations where it is more common due to founder mutation with a large cohort in Poland $(118,119)$.

Microcephaly at birth with distinct, "bird-like" craniofacial features as well as growth retardation and intellectual disability are early features of NBS $(120,121)$. Immunodeficiency is characterized by severe hypogammaglobulinemia in $20 \%$, IgA deficiency in 50\%, and reduced $\mathrm{B}$ and $\mathrm{T}$ cells in $>80 \%$ of NBS patients, resulting in a spectrum from silent phenotype to recurrent, chronic respiratory tract infections requiring immunoglobulin replacement (122-124). Malignancy is a significant cause of mortality in NBS patients. More than $40 \%$ of patients develop cancer, predominantly of lymphoid origin, by 20 years of age (125). Diffuse large B-cell lymphoma and $\mathrm{T}$ cell lymphoblastic lymphoma predominate (126). Other hematological malignancies including HL, B- and T-cell ALL, and AML have also been described (125). Solid malignancies such as medulloblastoma, rhabdomyosarcoma, papillary thyroid carcinoma, glioma, meningioma, neuroblastoma, and Ewing sarcoma occur rarely $(125,127,128)$.

\section{DNA Ligase IV Deficiency (LIGIV)}

LIGIV was clinically described in 1990 by Dr. Plowman et al., and in 1999, it was attributed to pathogenic mutations in DNA ligase IV (LIG4), located on 13q33.3 $(129,130)$. LIG4 mediates the final ligation step in the NHEJ pathway, a process utilized not only for NHEJ-mediated DSB repair but also for $\mathrm{V}(\mathrm{D}) \mathrm{J}$ recombination $(131,132)$. Approximately 40 cases have been reported with hypomorphic LIG4 mutations that correlate with clinical severity $(133,134)$. Patients present at variable ages with common features including microcephaly, facial dysmorphism, growth failure, infections, and severe immunodeficiency as well as hematological manifestations such as BMF and leukemia/lymphoma $(134,135)$. The immunologic phenotype can range from a radiosensitive T-B-NK+ severe combined immunodeficiency (SCID) to mild hypogammaglobulinemia and lymphopenia with restricted receptor repertoire (136). Hematological manifestations are largely due to accumulation of ionizing radiation and other genotoxic insults, resulting in BMF in $44 \%(134,137,138)$ and cancers in $24 \%$ of the patient population (134). Cancers of the hematopoietic system are most common and include lymphoid leukemia and lymphomas (EBV positive and negative) and AML 
$(130,134,135,139,140)$. Recently, in a cohort of patients with BMF/MDS, a novel homozygous mutation in LIG4 (c.2440C > T, p.R814X) was found in a 10-year-old boy presenting with MDS and monosomy 7 (141).

Genomic efforts have recently uncovered additional mutations in NHEJ repair genes, Artemis (DNA Cross-Link Repair 1C) and Cernunnos (XLF/NHEJ1), to cause hematological malignancies in anectodal reports. Compound heterozygous mutations in Artemis (EX1_3del and 1384_1390del), a key player in $\mathrm{V}(\mathrm{D}) \mathrm{J}$ recombinase machinery, was shown to cause EBV-associated B-cell lymphoma in a 9-month-old and a 5year-old patient (142). In a targeted mutation screen in children with hematological cytopenias, a novel homozygous NHEJ1 mutation (c.236T >C, p.L79P), involved in the final stage of DSB NHEJ repair, was identified as the causative genetic defect in a 21-year-old with MDS and monosomy 7 (143).

\section{SYNDROMES CAUSED BY ReCQ HELICASE FAMILY DEFICIENCIES}

Helicases allow access to the genome during replication, recombination, transcription, and repair by unraveling the double helix and other complex DNA and RNA structures in an ATP-dependent manner. RecQ helicases all possess three highly conserved domains: N-terminal ATPase-dependent helicase domain, RecQ-C middle domain with ability to bind various DNA structures, and a C-terminal helicase-and-ribonuclease-Dlike (HRDC) domain, which promotes DNA binding stability. $B L M$, WRN, RECQL1, RECQL4, and RECQL5 are five human RecQ helicases that are essential in maintaining genomic stability during DNA damage repair (144). So far, disease-causing mutations have been described in BLM, WRN, and RECQL4 to cause cancer predisposition syndromes: Bloom, Werner, and Rothmund-Thompson syndrome, respectively.

\section{Bloom Syndrome (BS)}

BS, initially described by Dr. David Bloom in 1954 (145), is an autosomal recessive disorder caused by biallelic mutations in BLM located at $15 \mathrm{q} 26.1$ (146). As of 2018, almost 300 cases were known to the Bloom Syndrome Registry (147) with predominance of individuals of Eastern European descent, particularly within the Ashkenazi Jewish population who have an estimated carrier rate of 1 in 100 (148). BLM prevents erroneous HR during replication and resolves intermediate DNA structures such as displacement loops and double Holliday junctions (149). In the absence of BLM, dysfunctional $\mathrm{HR}$ results in a 10fold increase in the rate of sister chromatid exchanges (SCEs) compared to healthy individuals (146).

Clinical features of BS include growth failure, sun-sensitive skin rash, endocrine disturbances, and immunodeficiency (150). BS neonates are small for gestational age with normal appearance with some exhibiting feeding difficulties resulting in failure to thrive (148). Photosensitive cutaneous rashes are among the most common manifestations that appear in infancy or early childhood and include telangiectasia erythema of the face (butterfly rash), hands, and forearms, as well as café-au-lait spots and hypopigmented macules (147). Immunodeficiency clinically manifests as frequent upper respiratory and gastrointestinal infections due to dysregulated $\mathrm{T}$ cells and hypogammaglobulinemia (particularly IgA and IgM deficiency) (150). Severe chronic lung disease is a common complication of BS thought to be secondary to repeated respiratory infections as a consequence of immunodeficiency (148). In addition to short stature, insulin resistance, type 2 diabetes, dyslipidemia, hypothyroidism, and impaired fertility are well-known endocrine sequalae that develop with age in BS patients $(151,152)$. Neurologically, BS patients have normal intelligence with very few cases reported with mild intellectual disability (152).

The distribution of cancers in BS patients is similar to that of the general population but with a younger age onset with at least one third of BS patients developing a malignancy by the age of 25 and $80 \%$ by the age of 40 years (147). Among 144 BS patients, 223 cancers were reported (147). Hematological cancers were most prevalent, with AML and ALL occurring most frequently with a median age of 18 years followed closely by lymphomas, (predominantly B-cell NHL) with a median age of diagnosis of 20 years (147). Colorectal carcinomas were the next most common solid tumors found in 28 of 223 cancers, with a median onset age of 37 years. Other common neoplasms include breast cancer, non-melanomatous basal and squamous cell skin carcinomas, and Wilms tumor (147).

\section{Werner Syndrome (WS)}

WS, previously known as adult onset progeria with cancer predisposition, is an autosomal recessive disorder initially reported by German medical student Otto Werner in 1904. He described a family of four siblings in their third decade of life that exhibited signs of premature aging, with graying of the hair, bilateral cataracts, scleroderma, and short stature (153), which was later attributed to biallelic mutations in the Werner (WRN) helicase (154). The prevalence is estimated at $1: 380,000-1: 1,000,000$ (155) and is higher in the Japanese (156) and Sardinian (157) population with an estimated frequency of 1:20,000-1:40,000 and 1:50,000, respectively. More than 70 different pathogenic mutations were found in the helicase and exonuclease domains of WRN located on locus 8p12 $(158,159)$. WRN has well-established functions in several DNA repair pathways, including NHEJ (158), HR (160), BER (161), and telomere maintenance (162).

The first presenting sign of WS is often short stature in a pre-adolescent individual failing to undergo a growth spurt. By the early third decade, ectodermal changes will become prominent featuring skin atrophy, graying or loss of hair, and bilateral cataracts (154) with readily discernable bird-like facies. Skin atrophy and calluses, which can progress to intractable ulcers, are common along with Achilles tendon calcification, a highly characteristic of WS in older patients (163). Common older age-associated endocrine abnormalities appear in the late 30 s, including type II diabetes, osteoporosis, and hypogonadism causing infertility $(154,163)$. Furthermore, WS patients suffer from premature and severe forms of atherosclerosis and medial artery calcification $(154,164)$. Surprisingly, there is a paucity of 
neurodegenerative changes in these patients in addition to lack of skeletal anomalies or intellectual disability $(154,165)$. Heart attacks and malignancies are the leading cause of morbidity in WS patients resulting in a low median life expectancy of 54 years (164). WS patients have a 2-60-fold increased risk for neoplasms, with thyroid follicular carcinomas as the most common cancer followed by melanoma, meningioma, sarcomas, leukemia/MDS, and primary bone tumors $(166,167)$.

The International Registry of Werner Syndrome has provided five cardinal signs for WS diagnosis in individuals $>10$ years of age: bilateral cataracts, characteristic skin changes, short stature, parental consanguinity or affected siblings, and premature hair graying (154). More than $90 \%$ of affected individuals had four cardinal features $(154,164)$. There is a subgroup of patients classified as atypical Werner syndrome (AWS), which is used to describe individuals with a clinical diagnosis of WS but a lack an identifiable WRN mutation. Of the 71 patients with AWS, a subset was shown to carry mutations in LMNA, a gene known to be mutated in the Hutchinson-Gilford Progeria syndrome (HGPS) (168), or in POLD1, a DNA polymerase involved in several DNA repair pathways (169). Thus, far, malignancies have not been reported among these AWS patients (154).

\section{Rothmund Thompson Syndrome (RTS)}

RTS was initially described by the German ophthalmologist Dr. August von Rothmund in 1868 with unique ectodermal features followed by a similar description by Dr. Sydney Thomson, British dermatologist, in 1921. It was not until 1957 when Dr. Taylor coined the syndrome, which now has almost 500 patients described in all ethnicity groups (170). RTS results from autosomal recessive germline mutations in RECQL4, which organizes the DNA replication machinery, promotes DNA end resection with MRN and CtIP complex during HR and promotes NHEJ in G1 phase of the cell cycle $(171,172)$.

Cutaneous rash is the hallmark clinical sign in RTS, which commonly presents in infancy with an erythematous facial rash that spreads to buttocks and extremities while sparing the trunk. The rash progresses to poikiloderma (reticulated hypo- and hyperpigmentation, telangiectasias, and punctate atrophy) over months to years and persists throughout life. Hyperkeratotic lesions and café-au-lait spots can manifest later $(170,173)$. Skeletal abnormalities and long bone defects were found in $75 \%$ of RTS patients (174). Ocular abnormalities occur with varying prevalence of $10-50 \%$ with rapid-onset bilateral cataracts being most frequent (175). Other common features include short stature, sparse or absent hair, dental anomalies, and feeding difficulties $(176,177)$. Immunodeficiency is uncommon, although IgG and IgA deficiencies along with T$\mathrm{B}+\mathrm{NK}$-combined immunodeficiency have been described (178180). The most common malignancy among RTS patients is osteosarcoma with a prevalence of $30 \%$, occurring at a younger median age of 11 years compared to the general population (177). Skin cancers, including melanoma and basal cell and squamous cell carcinoma, constitute the second most common cancer affecting $5 \%$ of patients $(177,181,182)$. Rare hematological malignancies include MDS, lymphomas (NHL, HL), and AML (173).
Notably, germline mutations in RECQL4 gene had also been associated with two other constitutional disorders with lymphoma risk. First, RAPADILINO (RAdial RAy defect; PAtellae hypoplasia or aplasia and cleft or highly arched PAlate; DIarrhea and DIslocated joints; LIttle size and LImb malformation; NOse slender and NOrmal intelligence) syndrome. It has been initially described in Finland in 1989 (183) to affect an estimated 1 in 75,000 individuals and manifest with pre- and post-natal growth failure, cervical spine defects, failure to thrive, and juvenile diarrhea of unknown cause (184). Lymphoma was reported in 4 patients and osteosarcoma in 1 patient with RAPADILINO syndrome (185). Second, BallerGerold syndrome (BGS), first reported by Cohen in 1975, was based on three patients described in 1950 by Baller and 1959 by Gerold in German literature (186). Fewer than 40 patients have been described with an unknown prevalence (187). BGS patients with RECQL4 mutations have craniosynostosis, upper-limb anomalies, short stature, and poikiloderma (188). Thus, far, only one case of malignancy (NK/T-cell lymphoma) has been reported in a 2.5-year-old individual with BGS (189).

\section{CANCER RISK AMONG HETEROZYGOUS MUTATION CARRIERS}

Individuals with germline heterozygous (monoallelic) mutations in some DNA repair genes have an increased lifetime risk of cancer, which is often facilitated by the acquisition of a somatic mutation affecting the remaining wild-type allele. The spectrum and onset age of cancers in individuals with heterozygous mutations differ compared to individuals with biallelic mutations in the same gene. Genetic counseling is recommended for all patients with, or at risk for having, monoallelic or biallelic DNA repair disorders due to the complex nature of these conditions and their associated health risks (190).

Cancer screening guidelines have been established by multiple organizations to address the need for increased surveillance and/or prophylactic management for these high-risk individuals (191-193). Gene-specific cancer screening guidelines have also been established internationally for individuals with monoallelic variant for a DNA repair disorder gene with high risk of cancer development (194-196). Many of these guidelines are region specific and may differ from recommendations, when available, in other parts of the world. Continued efforts to harmonize these recommendations are needed to ensure patients have access to appropriate management worldwide.

Monoallelic pathogenic mutations in the mismatch repair genes, $M L H 1, M S H 2, M S H 6, P M S 2$, and EPCAM, are associated with Lynch syndrome, a cancer predisposition syndrome characterized by an increased risk of colon cancer, uterine cancer, ovarian cancer, genitourinary tract cancers, and other gastrointestinal cancers. Cancer risk varies among the different MMR genes. Heterozygous mutations in PMS2, for instance, are associated with a lower risk of colon and endometrial cancers and are often diagnosed at later ages than in individuals with heterozygous mutations in MLH1 or MSH2 $(197,198)$. 
Heterozygous mutations in FA genes involved in DSB repair predispose to development of breast, ovarian, and other cancers. These include BRCA1 and BRCA2 mutations that confer a 50$80 \%$ lifetime breast cancer risk, $10-40 \%$ lifetime ovarian cancer risk, and increased risk of male breast, pancreatic, and prostate cancer, as well as melanoma $(199,200)$. Heterozygous loss of $P A L B 2$ has also been demonstrated to confer a susceptibility to breast and pancreatic cancer, as $P A L B 2$ interacts directly with both $B R C A 1$ and $B R C A 2$ during HR. An elevated risk of later onset serous ovarian cancer has been demonstrated in individuals with heterozygous loss-of-function $B R I P 1$ mutations (201). Biallelic mutations in BRCA1, BRCA2, PALB2, and BRIP1 result in FA groups $S, D 1, N$, and J, respectively. Recent metaanalyses have estimated that the lifetime risk of breast cancer in ATM heterozygotes is 33-38\% (115), although the c.7271T $>\mathrm{G}$ mutation may be associated with a significantly higher breast cancer risk (202). Heterozygous ATM mutations may also confer a susceptibility to pancreatic cancer (203). Heterozygous carriers of the NBN c.657del5 mutation (which is found in homozygous state in more than $90 \%$ of patients with Nijmegen breakage syndrome) who also carry two copies of the NBN polymorphism p.E185Q (GG allele) were shown to be at increased risk for breast and prostate cancers $(204,205)$. These recent studies are the first clear example of genetic modifier effect in a germline cancer syndrome, where the penetrance of a heterozygous allele is "activated" by the presence of an additional modifying polymorphism in the same gene.

\section{DIAGNOSTIC CONSIDERATIONS}

\section{History and Examination}

A thorough patient history, family history, and physical examination gives the first suspicion or a "red flag" pointing to an underlying DNA repair disorder (Table 2). Multisystem history should be obtained along with birth and developmental history since manifestations can appear at any location during the lifetime. If the patient has been treated for prior malignancy, age of diagnosis, type and location of cancer, treatment history, and hypersensitivity to chemotherapeutic agents should also be addressed. Family history features suggestive of one of these conditions include the presence of early-onset cancers in family members, multiple family members with cancer, or multiple cancers in one individual. Other concerning features include the presence of immunodeficiency, neurologic abnormalities, or deaths in young children from medical or unknown causes. Familial consanguinity should be noted because many of the DNA repair disorders are inherited in an autosomal recessive manner. Consideration should be given to the family's ethnic background as some of these disorders are enriched in specific ethnic populations secondary to founder mutations. Physical exam findings concerning DNA repair disorder include facial dysmorphology (particularly microcephaly, which should be evaluated by measuring head circumference); absent, sparse, brittle, or prematurely gray hair; as well as numerous dermatologic findings such as café-au-lait macules, hypopigmentation, multiple lentigines, telangiectasias, or rashes, especially if occurring on the face. An accurate height
TABLE 2 | The presence of multiple red flags in the medical and/or family history increases concern for an underlying DNA repair disorder and should warrant further evaluation.

\begin{tabular}{ll}
\hline & "Red flags" \\
\hline Constitutional features & Short stature \\
& Microcephaly \\
& Sparse or premature gray hair \\
& Photosensitivity \\
Skin & Pigmentation changes (hypo/hyperpigmentation) \\
& Poikiloderma \\
& Café-au-lait spots \\
& Teleangiectasias \\
& Pilomatricoma/pilomatrixoma (benign, hair follicle \\
& associated tumor) \\
& Butterfly shaped facial skin rash \\
& Intellectual disabilities \\
& Hyporeflexia \\
& Loss of fine or gross motor skills \\
& Ataxia \\
& Recurrent sinopulmonary infections \\
Heurologic & Hypogammaglobulinemia \\
T and B lymphocytopenia & Bone marrow failure \\
Hematologic & Pediatric cancers including head and neck, brain, \\
squamous cell carcinoma, melanoma, \\
adrenocortical carcinoma, NHL, MDS, AML \\
Family member with cancer below age 50, \\
especially if of breast, endometrial, or colorectal \\
origin \\
2 or more cancers in one individual/family \\
Multiple family members with similar or \\
related cancers \\
\\
\hline
\end{tabular}

should also be obtained, as many patients with a DNA repair disorder are of short stature. Suggestive neurologic findings include loss of deep tendon reflexes, spasticity, ataxia, or other gait changes. Referral to a clinical geneticist may also be of benefit to further assess for features of these conditions.

\section{Functional Assays}

Functional testing aids in the diagnostic workup of DNA repair disorders (Table 1). Telomere length is an important diagnostic tool that is used to diagnose short telomere syndromes such as dyskeratosis congenita, a BMF syndrome with mucocutaneous fragility and symptoms of premature aging with an increased predisposition to malignancies secondary to genetic deficiencies in telomere-associated genes such as TERT, TERC, DKC1, TINF1, and RTEL1 to name a few [excellent review provided by (206)]. Importantly, telomere length should be measured in DNA repair disorders such as FA (207, 208), AT (209, 210), NBS (211), BS (212), and WS (213) where patients exhibit short telomeres and chromosome end fusions secondary to dysfunctional DNA damage response at the telomere.

Chromosome breakage studies are necessary to establish a diagnosis of FA, as individuals with this condition are hypersensitive to crosslinking agents such as mitomycin $\mathrm{C}$ (MMC) or diepoxybutane (DEB). When exposed to these agents, patient cells will have an increased rate of chromosome breaks 
and aberrations such as radial figures and rearrangements. Rarely, mosaicism can occur in lymphocytes where two distinct lymphocyte populations are present with one subset having undergone spontaneous reversion resulting in normal sensitivity to clastogenic agents while the second population remains with the underlying genetic defect and retaining hypersensitivity features to damaging agents. Therefore, if breakage studies on lymphocytes are normal but there is still clinical suspicion for a DNA repair disorder, skin fibroblasts should be investigated to complete the diagnostic evaluation (76).

DNA repair disorders that present with profound immunodeficiency [AT, NBS, NHEJ deficiencies (Ligase IV, Artemis, Cernunnos)] can lead to absence or very low Tlymphocyte receptor excision circles (TRECs), which are detected on newborn screen $(214,215)$.

Spontaneous excess of immunoglobulin (Ig)/T-cell receptor (TCR) abnormal rearrangements of chromosomes 7 and 14 are common in patients with NBS (10-35\%) (216) and AT (5-10\%) (217). Alpha fetoprotein (AFP) is elevated in 95\% of AT patients (218), but interestingly, it can also be increased in FA patients (219). Sister chromatid exchange (SCE) assay, which assess for increased SCE in metaphase cells with bromodeoxyuridine (BrdU) exposure, aids in the diagnosis of BS (148). UV hypersensitivity assay, where skin fibroblasts are exposed to UV light, is used for diagnosing NER defect in XP patients, but this testing is typically completed in a research setting and may not be available clinically (220). There is a lack of consensus and uniform availability for a routine radiosensitivity assay available for patients with HR and NHEJ biallelic genetic disorders. Radiation-induced lymphocyte apoptosis (RILA) assay and phospho-ATM assay have some predictive potential (221). Analysis of radiation-induced $\gamma \mathrm{H} 2 \mathrm{AX}$ foci accumulation in $\mathrm{T}$ and NK lymphocytes of LIG4-SCID individuals was recently implemented as a flow cytometry assay (222).

\section{Genetic Testing}

It has become a standard approach to perform genetic studies as part of the initial diagnostic workup in a patient with a suspected DNA repair disorder based on clinical features and/or history of related malignancies. The patient's clinical phenotype and results of functional testing can be used to guide the differential diagnosis and, in turn, the genes requiring further investigation. Genetic testing of individuals presenting with a related malignancy but lacking other clinical manifestations of a DNA repair disorder is unlikely to have a high yield, as these conditions are thought to be rare. However, the diagnostic pickup of a DNA repair disorder in individuals with a related malignancy in an unbiased manner requires further study.

When ordering genetic testing, issues to consider include sample source, optimal genetic testing type, and technical challenges limiting mutation identification. First, peripheral blood or saliva samples are the easiest and most preferred sample source to obtain. In patients with active hematologic malignancy, however, skin fibroblasts or hair follicles are the preferred germline specimen (223). Single gene analysis may be an appropriate rapid approach in scenarios where a specific gene is expected based on phenotype. A disease-specific multigene panel is a cost-effective approach for patients with clinical features consistent with multiple DNA repair disorders. Currently, clinical whole exome or genome sequencing represent the most comprehensive approach, generally used after obtaining negative results from targeted gene testing. Some genes may present technical challenges, such as the PMS2 gene, which has multiple pseudogenes. One of these pseudogenes, PMS2CL, is part of a 100-kb inverted duplication and has close sequence homology to the regions of exons 9 and 11-15 in PMS2, making it difficult to differentiate whether the mutation is located within PMS2 or the pseudogene (224).

When interpreting variants obtained in genetic studies, it is widely accepted to use consensus criteria established by the American College of Medical Genetics and Genomics to classify variants as pathogenic, likely pathogenic, variant of uncertain significance (VUS), likely benign, and benign (225). Pathogenic and likely pathogenic variants will confirm a clinical diagnosis and thus impact medical management decisions. If a patient with a suspected autosomal recessive DNA repair disorder is found to have a heterozygous pathogenic mutation in a gene consistent with the phenotype, one has to consider that a second mutation within the same gene was missed. A discussion with the reporting lab may be helpful to clarify limitations of their testing strategy and whether additional testing may be warranted to evaluate for a second gene alteration, which might include not only a mutation but also an intragenic deletion or intronic variant. An increasingly growing challenge in the clinical setting is the finding of a VUS, for which the available genetic and functional data are either lacking or conflicting and, therefore, at a given time, they generally should not influence clinical decision making. However, periodic communication with the testing lab is encouraged to learn of any changes in variant interpretation that may occur over time.

\section{TREATMENT STRATEGIES}

A unifying feature among most DNA repair disorders is hypersensitivity to DNA-damaging agents such as radiation and chemotherapy used to treat malignancies. However, the underlying genetic deficit of repair pathway genes in patients with DNA repair syndromes places them at high risk for therapyrelated toxicities. For this reason, unique cancer treatment regimens are tailored that often employ reduced intensity doses to balance chemo- or radiotherapy-mediated toxicities while achieving clinical outcomes comparable to the standard of care. The high rate of treatment failures and secondary malignancies is problematic, especially in patients with CMMRD, NBS, and AT. Common strategies to avoid overt toxicities include avoiding radiomimetic drugs such as bleomycin and dactinomycin and being aware of cyclophosphamide- and/or ifosfamide-related hemorrhagic cystitis developing outside the normal range in patients with predisposition to telangiectasias. DSB DNA repair syndromes (AT, NBS, and LIGIV), due to their shared manifestations of immunodeficiency and increased risk for malignancies, benefit from reduced intensity conditioningbased hematopoietic stem cell transplantation (HSCT). However, 
the role of HSCT in improving overall outcome of patients with AT remains debatable (215). Several clinical trials are aimed at innovative drugs that target DNA repair genes to provide effective therapy while minimizing toxicities for patients with DNA repair disorder-associated cancers (226).

\section{CONCLUSIONS}

Cancer can result from mutations that are inherited or acquired during lifetime. DNA repair mechanisms are essential to maintenance of genomic integrity and are abrogated in cancer. Defects in DNA repair pathways result in a chaotic and unstable genomic environment, which is a hot bed for oncogenic transformation. This biological phenomenon is wellrecapitulated in classic DNA repair disorders that result from heritable mutations in genes essential for DNA damage response and result in early-onset cancers and premature aging. Because these syndromes are rare, a heightened awareness must be practiced to provide multidisciplinary care and surveillance and unique therapeutic considerations for patients with DNA repair disorders.

\section{REFERENCES}

1. Hoeijmakers JH. DNA damage, aging, and cancer. N Engl J Med. (2009) 361:1475-85. doi: 10.1056/NEJMra0804615

2. Chatterjee N, Walker GC. Mechanisms of DNA damage, repair, and mutagenesis. Environ Mol Mutagen. (2017) 58:235-63. doi: 10.1002/em.22087

3. Mehta A, Haber JE. Sources of DNA double-strand breaks and models of recombinational DNA repair. Cold Spring Harb Perspect Biol. (2014) 6:a016428. doi: 10.1101/cshperspect.a016428

4. Koster DA, Palle K, Bot ES, Bjornsti MA, Dekker NH. Antitumour drugs impede DNA uncoiling by topoisomerase I. Nature. (2007) 448:213-7. doi: $10.1038 /$ nature 05938

5. Jackson SP, Bartek J. The DNA-damage response in human biology and disease. Nature. (2009) 461:1071-8. doi: 10.1038/nature08467

6. Senturk E, Manfredi JJ. p53 and cell cycle effects after DNA damage. Methods Mol Biol. (2013) 962:49-61. doi: 10.1007/978-1-62703-236-0_4

7. Malkin D, Li FP, Strong LC, Fraumeni JF Jr, Nelson CE, Kim DH, et al. Germ line p53 mutations in a familial syndrome of breast cancer, sarcomas, other neoplasms. Science. (1990) 250:1233-8. doi: 10.1126/science.1978757

8. Valdez JM, Nichols KE, Kesserwan C. Li-Fraumeni syndrome: a paradigm for the understanding of hereditary cancer predisposition. Br J Haematol. (2017) 176:539-52. doi: 10.1111/bjh.14461

9. Kastan MB, Bartek J. Cell-cycle checkpoints and cancer. Nature. (2004) 432:316-23. doi: 10.1038/nature03097

10. Riley T, Sontag E, Chen P, Levine A. Transcriptional control of human p53-regulated genes. Nat Rev Mol Cell Biol. (2008) 9:402-12. doi: $10.1038 / \mathrm{nrm} 2395$

11. Caldecott KW. Single-strand break repair and genetic disease. Nat Rev Genet. (2008) 9:619-31. doi: 10.1038/nrg2380

12. Kuzminov A. Single-strand interruptions in replicating chromosomes cause double-strand breaks. Proc Natl Acad Sci USA. (2001) 98:8241-6. doi: $10.1073 /$ pnas. 131009198

13. Kathe SD, Shen GP, Wallace SS. Single-stranded breaks in DNA but not oxidative DNA base damages block transcriptional elongation by RNA polymerase II in HeLa cell nuclear extracts. J Biol Chem. (2004) 279:1851120. doi: 10.1074/jbc.M313598200

14. Zhou W, Doetsch PW. Transcription bypass or blockage at single-strand breaks on the DNA template strand: effect of different 3' and 5' flanking

\section{AUTHOR CONTRIBUTIONS}

RS and SL wrote and revised the manuscript. All authors contributed to the article and approved the submitted version.

\section{FUNDING}

This work was supported by ALSAC/St. Jude Children's Research Hospital, and grants to MW: Fritz-Thyssen Foundation (10.17.1.026MN), ERAPERMED GATA2HuMo (2018-123, 01KU1904), Deutsche Krebshilfe (109005), Deutsche Kinderkrebsstifung (DKS 2017.03), and BMBF MyPred (01GM1911A).

\section{ACKNOWLEDGMENTS}

The authors thank Mitch Weiss, Michelle Boals, and Nathan Gray and other members of the St. Jude Bone Marrow Failure/MDS program, as well as Dr. Kim Nichols and the St. Jude Division of Cancer Predisposition for patient management and helpful discussions.

groups on the T7 RNA polymerase elongation complex. Biochemistry. (1994) 33:14926-34. doi: 10.1021/bi00253a032

15. Bacolla A, Cooper DN, Vasquez KM. Mechanisms of base substitution mutagenesis in cancer genomes. Genes. (2014) 5:108-46. doi: 10.3390/genes5010108

16. Rivera B, Castellsague E, Bah I, van Kempen LC, Foulkes WD. Biallelic NTHL1 mutations in a woman with multiple primary tumors. $N$ Engl J Med. (2015) 373:1985-86. doi: 10.1056/NEJMc1506878

17. Venesio T, Balsamo A, D’Agostino VG, Ranzani GN. MUTYH-associated polyposis (MAP), the syndrome implicating base excision repair in inherited predisposition to colorectal tumors. Front Oncol. (2012) 2:83. doi: 10.3389/fonc. 2012.00083

18. Hebra F, Kaposi M. On diseases of the skin including exanthemata, volume III. N Syndenham Soc. (1874) 61:252-8.

19. Kleijer WJ, Laugel V, Berneburg M, Nardo T, Fawcett H, Gratchev A, et al. Incidence of DNA repair deficiency disorders in western Europe: xeroderma pigmentosum, Cockayne syndrome and trichothiodystrophy. DNA Repair. (2008) 7:744-50. doi: 10.1016/j.dnarep.2008.01.014

20. Kraemer KH, Lee MM, Scotto J. Xeroderma pigmentosum. cutaneous, ocular, and neurologic abnormalities in 830 published cases. Arch Dermatol. (1987) 123:241-50. doi: 10.1001/archderm.123.2.241

21. Hirai Y, Kodama Y, Moriwaki S, Noda A, Cullings HM, Macphee DG, et al. Heterozygous individuals bearing a founder mutation in the XPA DNA repair gene comprise nearly $1 \%$ of the Japanese population. Mutat Res. (2006) 601:171-8. doi: 10.1016/j.mrfmmm.2006.06.010

22. Soufir N, Ged C, Bourillon A, Austerlitz F, Chemin C, Stary A, et al. A prevalent mutation with founder effect in xeroderma pigmentosum group C from north Africa. J Invest Dermatol. (2010) 130:1537-42. doi: 10.1038/jid.2009.409

23. Lehmann AR. DNA repair-deficient diseases, xeroderma pigmentosum, Cockayne syndrome and trichothiodystrophy. Biochimie. (2003) 85:1101-11. doi: 10.1016/j.biochi.2003.09.010

24. Fassihi H, Sethi M, Fawcett H, Wing J, Chandler N, Mohammed S, et al. Deep phenotyping of 89 xeroderma pigmentosum patients reveals unexpected heterogeneity dependent on the precise molecular defect. Proc Natl Acad Sci USA. (2016) 113:E1236-E1245. doi: 10.1073/pnas.1519444113

25. Berneburg M, Lehmann AR. Xeroderma pigmentosum and related disorders: defects in DNA repair and transcription. Adv Genet. (2001) 43:71-102. doi: 10.1016/S0065-2660(01)43004-5 
26. Sethi M, Lehmann AR, Fawcett H, Stefanini M, Jaspers N, Mullard K, et al. Patients with xeroderma pigmentosum complementation groups $\mathrm{C}, \mathrm{E}$ and $\mathrm{V}$ do not have abnormal sunburn reactions. Br J Dermatol. (2013) 169:1279-87. doi: 10.1111/bjd.12523

27. Ramkumar HL, Brooks BP, Cao X, Tamura D, Digiovanna JJ, Kraemer $\mathrm{KH}$, et al. Ophthalmic manifestations and histopathology of xeroderma pigmentosum: two clinicopathological cases and a review of the literature. Surv Ophthalmol. (2011) 56:348-61. doi: 10.1016/j.survophthal.2011.03.001

28. Andrews $\mathrm{AD}$, Barrett SF, Robbins JH. Xeroderma pigmentosum neurological abnormalities correlate with colony-forming ability after ultraviolet radiation. Proc Natl Acad Sci USA. (1978) 75:1984-8. doi: 10.1073/pnas.75.4.1984

29. Bradford PT, Goldstein AM, Tamura D, Khan SG, Ueda T, Boyle J, et al. Cancer and neurologic degeneration in xeroderma pigmentosum: long term follow-up characterises the role of DNA repair. J Med Genet. (2011) 48:16876. doi: 10.1136/jmg.2010.083022

30. Kraemer KH, Patronas NJ, Schiffmann R, Brooks BP, Tamura D, DiGiovanna JJ. Xeroderma pigmentosum, trichothiodystrophy and Cockayne syndrome: a complex genotype-phenotype relationship. Neuroscience. (2007) 145:138896. doi: 10.1016/j.neuroscience.2006.12.020

31. Butt FM, Moshi JR, Owibingire S, Chindia ML. Xeroderma pigmentosum: a review and case series. J Craniomaxillofac Surg. (2010) 38:534-7. doi: 10.1016/j.jcms.2010.02.006

32. DiGiovanna JJ, Patronas N, Katz D, Abangan D, Kraemer KH. Xeroderma pigmentosum: spinal cord astrocytoma with 9-year survival after radiation and isotretinoin therapy. J Cutan Med Surg. (1998) 2:153-8. doi: $10.1177 / 120347549800200308$

33. Sarasin A, Quentin S, Droin N, Sahbatou M, Saada V, Auger N, et al. Familial predisposition to TP53/complex karyotype MDS and leukemia in DNA repair-deficient xeroderma pigmentosum. Blood. (2019) 133:2718-24. doi: 10.1182/blood-2019-01-895698

34. Giglia G, Dumaz N, Drougard C, Avril MF, Daya-Grosjean L, Sarasin A. p53 mutations in skin and internal tumors of xeroderma pigmentosum patients belonging to the complementation group C. Cancer Res. (1998) 58:4402-9.

35. Spivak G. Nucleotide excision repair in humans. DNA Repair. (2015) 36:138. doi: 10.1016/j.dnarep.2015.09.003

36. Tiwari V, Wilson DM III. DNA Damage and associated DNA repair defects in disease and premature aging. Am J Hum Genet. (2019) 105:237-57. doi: 10.1016/j.ajhg.2019.06.005

37. Johnson RE, Kondratick CM, Prakash S, Prakash L. hRAD30 mutations in the variant form of xeroderma pigmentosum. Science. (1999) 285:263-5. doi: $10.1126 /$ science.285.5425.263

38. Masutani C, Kusumoto R, Yamada A, Dohmae N, Yokoi M, Yuasa M, et al. The XPV (xeroderma pigmentosum variant) gene encodes human DNA polymerase eta. Nature. (1999) 399:700-4. doi: 10.1038/21447

39. Reid-Bayliss KS, Arron ST, Loeb LA, Bezrookove V, Cleaver JE. Why Cockayne syndrome patients do not get cancer despite their DNA repair deficiency. Proc Natl Acad Sci USA. (2016) 113:10151-6. doi: 10.1073/pnas.1610020113

40. Berneburg M, Clingen PH, Harcourt SA, Lowe JE, Taylor EM, Green MH, et al. The cancer-free phenotype in trichothiodystrophy is unrelated to its repair defect. Cancer Res. (2000) 60:431-8. Available online at: https:// cancerres.aacrjournals.org/content/60/2/431

41. Wilson CJ, Chao DM, Imbalzano AN, Schnitzler GR, Kingston RE, Young RA. RNA polymerase II holoenzyme contains SWI/SNF regulators involved in chromatin remodeling. Cell. (1996) 84:235-44. doi: 10.1016/S0092-8674(00)80978-2

42. Tummala H, Dokal AD, Walne A, Ellison A, Cardoso S, Amirthasigamanipillai S, et al. Genome instability is a consequence of transcription deficiency in patients with bone marrow failure harboring biallelic ERCC6L2 variants. Proc Natl Acad Sci USA. (2018) 115:7777-82. doi: 10.1073/pnas.1803275115

43. Weterings E, Chen DJ. DNA-dependent protein kinase in nonhomologous end joining: a lock with multiple keys? J Cell Biol. (2007) 179:183-6. doi: $10.1083 /$ jcb.200705106

44. Tummala H, Kirwan M, Walne AJ, Hossain U, Jackson N, Pondarre C, et al. ERCC6L2 mutations link a distinct bone-marrow-failure syndrome to DNA repair and mitochondrial function. Am J Hum Genet. (2014) 94:246-56. doi: 10.1016/j.ajhg.2014.01.007
45. Bluteau O, Sebert M, Leblanc T, Peffault de Latour R, Quentin S, Lainey E, et al. A landscape of germ line mutations in a cohort of inherited bone marrow failure patients. Blood. (2018) 131:717-32. doi: 10.1182/blood-2017-09-806489

46. Douglas SPM, Siipola P, Kovanen PE, Pyorala M, Kakko S, Savolainen $\mathrm{ER}$, et al. ERCC6L2 defines a novel entity within inherited acute myeloid leukemia. Blood. (2019) 133:2724-8. doi: 10.1182/blood-2019-01-8 96233

47. Ricciardone MD, Ozcelik T, Cevher B, Ozdag H, Tuncer M, Gurgey A, et al. Human MLH1 deficiency predisposes to hematological malignancy and neurofibromatosis type 1. Cancer Res. (1999) 59:290-3.

48. Wang Q, Lasset C, Desseigne F, Frappaz D, Bergeron C, Navarro C, et al. Neurofibromatosis and early onset of cancers in hMLH1-deficient children. Cancer Res. (1999) 59:294-7.

49. Wimmer K, Kratz CP. Constitutional mismatch repair-deficiency syndrome. Haematologica. (2010) 95:699-701. doi: 10.3324/haematol.2009.021626

50. Hsieh P, Yamane K. DNA mismatch repair: molecular mechanism, cancer, and ageing. Mech Ageing Dev. (2008) 129:391-407. doi: 10.1016/j.mad.2008.02.012

51. Silva FC, Valentin MD, Ferreira Fde O, Carraro DM, Rossi BM. Mismatch repair genes in Lynch syndrome: a review. Saõ Paulo Med J. (2009) 127:4651. doi: 10.1590/S1516-31802009000100010

52. Peltomaki P. Update on Lynch syndrome genomics. Fam Cancer. (2016) 15:385-93. doi: 10.1007/s10689-016-9882-8

53. Wimmer K, Kratz CP, Vasen HF, Caron O, Colas C, Entz-Werle N, et al. Diagnostic criteria for constitutional mismatch repair deficiency syndrome: suggestions of the European consortium 'care for CMMRD' (C4CMMRD). J Med Genet. (2014) 51:355-65. doi: 10.1136/jmedgenet-2014-102284

54. Lavoine N, Colas C, Muleris M, Bodo S, Duval A, Entz-Werle N, et al. Constitutional mismatch repair deficiency syndrome: clinical description in a French cohort. J Med Genet. (2015) 52:770-8. doi: 10.1136/jmedgenet-2015-103299

55. Aaltonen LA, Peltomaki P, Leach FS, Sistonen P, Pylkkanen L, Mecklin JP, et al. Clues to the pathogenesis of familial colorectal cancer. Science. (1993) 260:812-6. doi: 10.1126/science.8484121

56. Lynch HT, Lynch JF, Attard TA. Diagnosis and management of hereditary colorectal cancer syndromes: Lynch syndrome as a model. CMAJ. (2009) 181:273-80. doi: 10.1503/cmaj.071574

57. Shlien A, Campbell BB, de Borja R, Alexandrov LB, Merico D, Wedge D, et al. Combined hereditary and somatic mutations of replication error repair genes result in rapid onset of ultra-hypermutated cancers. Nat Genet. (2015) 47:257-62. doi: 10.1038/ng.3202

58. Bouffet E, Larouche V, Campbell, BB, Merico, D, de Borja R, Aronson $\mathrm{M}$, et al. Immune checkpoint inhibition for hypermutant glioblastoma multiforme resulting from germline biallelic mismatch repair deficiency. $J$ Clin Oncol. (2016) 34:2206-11. doi: 10.1200/JCO.2016.66.6552

59. Bellido F, Pineda M, Aiza G, Valdes-Mas R, Navarro M, Puente DA, et al. POLE and POLD1 mutations in 529 kindred with familial colorectal cancer and/or polyposis: review of reported cases and recommendations for genetic testing and surveillance. Genet Med. (2016) 18:325-32. doi: 10.1038/gim.2015.75

60. Esteban-Jurado C, Gimenez-Zaragoza D, Munoz J, Franch-Exposito S, Alvarez-Barona M, Ocana T, et al. POLE and POLD1 screening in 155 patients with multiple polyps and early-onset colorectal cancer. Oncotarget. (2017) 8:26732-43. doi: 10.18632/oncotarget.15810

61. Franch-Exposito S, Esteban-Jurado C, Garre P, Quintanilla I, DuranSanchon S, Diaz-Gay M, et al. Rare germline copy number variants in colorectal cancer predisposition characterized by exome sequencing analysis. J Genet Genomics. (2018) 45:41-5. doi: 10.1016/j.jgg.2017.12.001

62. Hansen MF, Johansen J, Bjornevoll I, Sylvander AE, Steinsbekk KS, Saetrom P, et al. A novel POLE mutation associated with cancers of colon, pancreas, ovaries and small intestine. Fam Cancer. (2015) 14:437-48. doi: $10.1007 /$ s10689-015-9803-2

63. Lindsay H, Scollon S, Reuther J, Voicu H, Rednam SP, Lin FY, et al. Germline POLE mutation in a child with hypermutated medulloblastoma and features of constitutional mismatch repair deficiency. Cold Spring Harb Mol Case Stud. (2019) 5:ea004499. doi: 10.1101/mcs.a004499

64. Wimmer K, Beilken A, Nustede R, Ripperger T, Lamottke B, Ure B, et al. A novel germline POLE mutation causes an early onset cancer prone syndrome 
mimicking constitutional mismatch repair deficiency. Fam Cancer. (2017) 16:67-71. doi: 10.1007/s10689-016-9925-1

65. Kempers MJ, Kuiper RP, Ockeloen CW, Chappuis PO, Hutter P, Rahner N, et al. Risk of colorectal and endometrial cancers in EPCAM deletion-positive Lynch syndrome: a cohort study. Lancet Oncol. (2011) 12:49-55. doi: 10.1016/S1470-2045(10)70265-5

66. Adam R, Spier I, Zhao B, Kloth M, Marquez J, Hinrichsen I, et al. Exome sequencing identifies biallelic MSH3 germline mutations as a recessive subtype of colorectal adenomatous polyposis. Am J Hum Genet. (2016) 99:337-51. doi: 10.1016/j.ajhg.2016.06.015

67. Vasen HF, Ghorbanoghli Z, Bourdeaut F, Cabaret O, Caron O, Duval A, et al. Guidelines for surveillance of individuals with constitutional mismatch repair-deficiency proposed by the European Consortium “Care for CMMR-D” (C4CMMR-D). J Med Genet. (2014) 51:283-93. doi: 10.1136/jmedgenet-2013-102238

68. Ramchander NC, Ryan NA, Crosbie EJ, Evans DG. Homozygous germline mutation of the PMS2 mismatch repair gene: a unique case report of constitutional mismatch repair deficiency (CMMRD). BMC Med Genet. (2017) 18:40. doi: 10.1186/s12881-017-0391-x

69. Wimmer K, Etzler J. Constitutional mismatch repair-deficiency syndrome: have we so far seen only the tip of an iceberg? Hum Genet. (2008) 124:105-22. doi: 10.1007/s00439-008-0542-4

70. Ripperger T, Schlegelberger B. Acute lymphoblastic leukemia and lymphoma in the context of constitutional mismatch repair deficiency syndrome. Eur J Med Genet. (2016) 59:133-42. doi: 10.1016/j.ejmg.2015.12.014

71. Johnson RD, Jasin M. Sister chromatid gene conversion is a prominent double-strand break repair pathway in mammalian cells. EMBO J. (2000) 19:3398-407. doi: 10.1093/emboj/19.13.3398

72. Petronczki M, Siomos MF, Nasmyth K. Un menage a quatre: the molecular biology of chromosome segregation in meiosis. Cell. (2003) 112:423-40. doi: 10.1016/S0092-8674(03)00083-7

73. Pannunzio NR, Watanabe G, Lieber MR. Nonhomologous DNA end-joining for repair of DNA double-strand breaks. J Biol Chem. (2018) 293:10512-23. doi: 10.1074/jbc.TM117.000374

74. Chang HHY, Pannunzio NR, Adachi N, Lieber MR. Non-homologous DNA end joining and alternative pathways to double-strand break repair. Nat Rev Mol Cell Biol. (2017) 18:495-506. doi: 10.1038/nrm.2017.48

75. Fanconi G. Familiäre infantile perniziosaartige Anämie (pernizioses Blutbild und Konstitution). Jahrb Kinderh. (1927) 117:257-80.

76. Auerbach AD. Fanconi anemia and its diagnosis. Mutat Res. (2009) 668:4-10. doi: 10.1016/j.mrfmmm.2009.01.013

77. Bluteau D, Masliah-Planchon J, Clairmont C, Rousseau A, Ceccaldi R, Dubois d'Enghien C, et al. Biallelic inactivation of REV7 is associated with Fanconi anemia. J Clin Invest. (2016) 126:3580-4. doi: 10.1172/JCI 88010

78. McCauley J, Masand N, McGowan R, Rajagopalan S, Hunter A, Michaud JL, et al. X-linked VACTERL with hydrocephalus syndrome: further delineation of the phenotype caused by FANCB mutations. Am J Med Genet A. (2011) 155A:2370-80. doi: 10.1002/ajmg.a.33913

79. Park JY, Virts EL, Jankowska A, Wiek C, Othman M, Chakraborty SC, et al. Complementation of hypersensitivity to DNA interstrand crosslinking agents demonstrates that XRCC2 is a Fanconi anaemia gene. J Med Genet. (2016) 53:672-80. doi: 10.1136/jmedgenet-2016-103847

80. Wang AT, Smogorzewska A. SnapShot: fanconi anemia and associated proteins. Cell. (2015) 160:354.e1. doi: 10.1016/j.cell.2014. 12.031

81. Knies K, Inano S, Ramirez MJ, Ishiai M, Surralles J, Takata M, et al. Biallelic mutations in the ubiquitin ligase RFWD3 cause Fanconi anemia. J Clin Invest. (2017) 127:3013-27. doi: 10.1172/JCI92069

82. Alter BP, Giri N, Savage SA, Rosenberg PS. Cancer in the National Cancer Institute inherited bone marrow failure syndrome cohort after fifteen years of follow-up. Haematologica. (2018) 103:30-9. doi: 10.3324/haematol.2017.178111

83. Fiesco-Roa MO, Giri N, McReynolds LJ, Best AF, Alter BP. Genotypephenotype associations in Fanconi anemia: a literature review. Blood Rev. (2019) 37:100589. doi: 10.1016/j.blre.2019.100589

84. Nalepa G, Clapp DW. Fanconi anaemia and cancer: an intricate relationship. Nat Rev Cancer. (2018) 18:168-85. doi: 10.1038/nrc.2017.116
85. Niraj J, Farkkila A, D'Andrea AD. The Fanconi anemia pathway in cancer. Annu Rev Cancer Biol. (2019) 3:457-78. doi: 10.1146/annurev-cancerbio-030617-050422

86. Boder E, Sedgwick RP. Ataxia-telangiectasia; a familial syndrome of progressive cerebellar ataxia, oculocutaneous telangiectasia and frequent pulmonary infection. Pediatrics. (1958) 21:526-54.

87. Swift M, Morrell D, Cromartie E, Chamberlin AR, Skolnick MH, Bishop DT. The incidence and gene frequency of ataxia-telangiectasia in the United States. Am J Hum Genet. (1986) 39:573-83.

88. Rothblum-Oviatt C, Wright J, Lefton-Greif MA, McGrath-Morrow SA, Crawford TO, Lederman HM. Ataxia telangiectasia: a review. Orphanet $J$ Rare Dis. (2016) 11:159. doi: 10.1186/s13023-016-0543-7

89. Savitsky K, Bar-Shira A, Gilad S, Rotman G, Ziv Y, Vanagaite L, et al. A single ataxia telangiectasia gene with a product similar to PI-3 kinase. Science. (1995) 268:1749-53. doi: 10.1126/science.7792600

90. Gatti RA, Berkel I, Boder E, Braedt G, Charmley P, Concannon P, et al. Localization of an ataxia-telangiectasia gene to chromosome 11q22-23. Nature. (1988) 336:577-80. doi: 10.1038/336577a0

91. Khanna KK, Lavin MF, Jackson SP, Mulhern TD. ATM, a central controller of cellular responses to DNA damage. Cell Death Differ. (2001) 8:1052-65. doi: $10.1038 /$ sj.cdd. 4400874

92. Lavin MF. ATM and the Mrel1 complex combine to recognize and signal DNA double-strand breaks. Oncogene. (2007) 26:7749-58. doi: 10.1038/sj.onc. 1210880

93. Bolderson E, Scorah J, Helleday T, Smythe C, Meuth M. ATM is required for the cellular response to thymidine induced replication fork stress. $\mathrm{Hum} \mathrm{Mol}$ Genet. (2004) 13:2937-45. doi: 10.1093/hmg/ddh316

94. Cortez D, Wang Y, Qin J, Elledge SJ. Requirement of ATM-dependent phosphorylation of brcal in the DNA damage response to double-strand breaks. Science. (1999) 286:1162-6. doi: 10.1126/science.286.5442.1162

95. Choi M, Kipps T, Kurzrock R. ATM mutations in cancer: therapeutic implications. Mol Cancer Ther. (2016) 15:1781-91. doi: 10.1158/1535-7163.MCT-15-0945

96. Matsuoka S, Ballif BA, Smogorzewska A, McDonald ER III, Hurov KE, Luo J, et al. ATM and ATR substrate analysis reveals extensive protein networks responsive to DNA damage. Science. (2007) 316:1160-6. doi: 10.1126/science.1140321

97. Gilad S, Chessa L, Khosravi R, Russell P, Galanty Y, Piane M, et al. Genotypephenotype relationships in ataxia-telangiectasia and variants. Am J Hum Genet. (1998) 62:551-61. doi: 10.1086/301755

98. Verhagen MM, Last JI, Hogervorst FB, Smeets DF, Roeleveld N, Verheijen F, et al. Presence of ATM protein and residual kinase activity correlates with the phenotype in ataxia-telangiectasia: a genotype-phenotype study. Hum Mutat. (2012) 33:561-71. doi: 10.1002/humu.22016

99. Boder E. Ataxia-telangiectasia: an overview. Kroc Found Ser. (1985) 19:1-63.

100. Crawford TO. Ataxia telangiectasia. Semin Pediatr Neurol. (1998) 5:287-94. doi: 10.1016/S1071-9091(98)80007-7

101. Hoche F, Seidel K, Theis M, Vlaho S, Schubert R, Zielen S, et al. Neurodegeneration in ataxia telangiectasia: what is new? What is evident? Neuropediatrics. (2012) 43:119-29. doi: 10.1055/s-0032-1313915

102. Pearson TS. More than ataxia: hyperkinetic movement disorders in childhood autosomal recessive ataxia syndromes. Tremor Other Hyperkinet Mov. (2016) 6:368. doi: 10.5334/tohm.319

103. Cabana MD, Crawford TO, Winkelstein JA, Christensen JR, Lederman HM. Consequences of the delayed diagnosis of ataxia-telangiectasia. Pediatrics. (1998) 102:98-100. doi: 10.1542/peds.102.1.98

104. Driessen GJ, Ijspeert H, Weemaes CM, Haraldsson A, Trip M, Warris A, et al. Antibody deficiency in patients with ataxia telangiectasia is caused by disturbed B- and T-cell homeostasis and reduced immune repertoire diversity. J Allergy Clin Immunol. (2013) 131:1367-75.e9. doi: 10.1016/j.jaci.2013.01.053

105. Kraus M, Lev A, Simon AJ, Levran I, Nissenkorn A, Levi YB, et al. Disturbed $\mathrm{B}$ and $\mathrm{T}$ cell homeostasis and neogenesis in patients with ataxia telangiectasia. J Clin Immunol. (2014) 34:561-72. doi: 10.1007/s10875-014-0044-1

106. Nowak-Wegrzyn A, Crawford TO, Winkelstein JA, Carson KA, Lederman HM. Immunodeficiency and infections in ataxia-telangiectasia. J Pediatr. (2004) 144:505-11. doi: 10.1016/j.jpeds.2003.12.046 
107. Noordzij JG, Wulffraat NM, Haraldsson A, Meyts I, van't Veer LJ, Hogervorst FB, et al. (2009). Ataxia-telangiectasia patients presenting with hyper-IgM syndrome. Arch Dis Child. 94:448-9. doi: 10.1136/adc.2008.149351

108. Chiam LY, Verhagen MM, Haraldsson A, Wulffraat N, Driessen GJ, Netea MG, et al. (2011). Cutaneous granulomas in ataxia telangiectasia and other primary immunodeficiencies: reflection of inappropriate immune regulation? Dermatology. 223:13-9. doi: 10.1159/000330335

109. Schroeder SA, Zielen S. Infections of the respiratory system in patients with ataxia-telangiectasia. Pediatr Pulmonol. (2014) 49:389-99. doi: 10.1002/ppul.22817

110. Connelly PJ, Smith N, Chadwick R, Exley AR, Shneerson JM, Pearson ER. Recessive mutations in the cancer gene Ataxia Telangiectasia Mutated (ATM), at a locus previously associated with metformin response, cause dysglycaemia and insulin resistance. Diabet Med. (2016) 33:371-5. doi: 10.1111/dme.13037

111. Voss S, Pietzner J, Hoche F, Taylor AM, Last JI, Schubert R, et al. Growth retardation and growth hormone deficiency in patients with Ataxia telangiectasia. Growth Factors. (2014) 32:123-9. doi: 10.3109/08977194.2014.939805

112. Xu Y, Ashley T, Brainerd EE, Bronson RT, Meyn MS, Baltimore D. Targeted disruption of ATM leads to growth retardation, chromosomal fragmentation during meiosis, immune defects, thymic lymphoma. Genes Dev. (1996) 10:2411-22. doi: 10.1101/gad.10.19.2411

113. Reiman A, Srinivasan V, Barone G, Last JI, Wootton LL, Davies EG, et al. Lymphoid tumours and breast cancer in ataxia telangiectasia; substantial protective effect of residual ATM kinase activity against childhood tumours. Br J Cancer. (2011) 105:586-91. doi: 10.1038/bjc.2011.266

114. Suarez F, Mahlaoui N, Canioni D, Andriamanga C, Dubois d'Enghien C, Brousse $\mathrm{N}$, et al. Incidence, presentation, and prognosis of malignancies in ataxia-telangiectasia: a report from the French national registry of primary immune deficiencies. J Clin Oncol. (2015) 33:202-8. doi: 10.1200/JCO.2014.56.5101

115. van Os NJH, Roeleveld N, Weemaes CM, Jongmans MC, Janssens GO, Taylor $\mathrm{AM}$, et al. Health risks for ataxia-telangiectasia mutated heterozygotes: a systematic review, meta-analysis and evidence-based guideline. Clin Genet. (2016) 90:105-17. doi: 10.1111/cge.12710

116. Lee JH, Paull TT. ATM activation by DNA double-strand breaks through the Mre11-Rad50-Nbs1 complex. Science. (2005) 308:551-4. doi: $10.1126 /$ science. 1108297

117. Weemaes CM, Hustinx TW, Scheres JM, van Munster PJ, Bakkeren JA, Taalman RD. A new chromosomal instability disorder: the Nijmegen breakage syndrome. Acta Paediatr Scand. (1981) 70:557-64. doi: 10.1111/j.1651-2227.1981.tb05740.x

118. Varon R, Vissinga C, Platzer M, Cerosaletti KM, Chrzanowska KH, Saar K, et al. Nibrin, a novel DNA double-strand break repair protein, is mutated in Nijmegen breakage syndrome. Cell. (1998) 93:467-76. doi: 10.1016/S0092-8674(00)81174-5

119. The International Nijmegen Breakage Syndrome Study Group. Nijmegen breakage syndrome. Arch Dis Child. (2000) 82:400-6. doi: $10.1136 /$ adc.82.5.400

120. Digweed M, Sperling K. Nijmegen breakage syndrome: clinical manifestation of defective response to DNA double-strand breaks. DNA Repair. (2004) 3:1207-17. doi: 10.1016/j.dnarep.2004.03.004

121. Seeman P, Gebertova K, Paderova K, Sperling K, Seemanova E. Nijmegen breakage syndrome in $13 \%$ of age-matched Czech children with primary microcephaly. Pediatr Neurol. (2004) 30:195-200. doi: 10.1016/j.pediatrneurol.2003.07.003

122. Gregorek H, Chrzanowska KH, Michalkiewicz J, Syczewska M, Madalinski K. Heterogeneity of humoral immune abnormalities in children with Nijmegen breakage syndrome: an 8-year follow-up study in a single centre. Clin Exp Immunol. (2002) 130:319-24. doi: 10.1046/j.1365-2249.2002.01971.x

123. Michalkiewicz J, Barth C, Chrzanowska K, Gregorek H, Syczewska M, Weemaes CM, et al. Abnormalities in the T and NK lymphocyte phenotype in patients with Nijmegen breakage syndrome. Clin Exp Immunol. (2003) 134:482-90. doi: 10.1046/j.1365-2249.2003.02285.x

124. Wolska-Kusnierz B, Gregorek H, Chrzanowska K, Piatosa B, Pietrucha B, Heropolitanska-Pliszka E, et al. Nijmegen breakage syndrome: clinical and immunological features, long-term outcome and treatment options - a retrospective analysis. J Clin Immunol. (2015) 35:538-49. doi: 10.1007/s10875-015-0186-9

125. Chrzanowska KH, Gregorek H, Dembowska-Baginska B, Kalina MA, Digweed M. Nijmegen breakage syndrome (NBS). Orphanet J Rare Dis. (2012) 7:13. doi: 10.1186/1750-1172-7-13

126. Dembowska-Baginska B, Perek D, Brozyna A, Wakulinska A, OlczakKowalczyk D, Gladkowska-Dura M, et al. Non-Hodgkin lymphoma (NHL) in children with Nijmegen Breakage syndrome (NBS). Pediatr Blood Cancer. (2009) 52:186-90. doi: 10.1002/pbc.21789

127. Distel L, Neubauer S, Varon R, Holter W, Grabenbauer G. Fatal toxicity following radio- and chemotherapy of medulloblastoma in a child with unrecognized Nijmegen breakage syndrome. Med Pediatr Oncol. (2003) 41:44-8. doi: 10.1002/mpo.10275

128. Meyer S, Kingston H, Taylor AM, Byrd PJ, Last JI, Brennan BM, et al. Rhabdomyosarcoma in Nijmegen breakage syndrome: strong association with perianal primary site. Cancer Genet Cytogenet. (2004) 154:169-74. doi: 10.1016/j.cancergencyto.2004.02.022

129. Plowman PN, Bridges BA, Arlett CF, Hinney A, Kingston JE. An instance of clinical radiation morbidity and cellular radiosensitivity, not associated with ataxia-telangiectasia. Br J Radiol. (1990) 63:624-8. doi: 10.1259/0007-1285-63-752-624

130. Riballo E, Critchlow SE, Teo SH, Doherty AJ, Priestley A, Broughton B, et al. Identification of a defect in DNA ligase IV in a radiosensitive leukaemia patient. Curr Biol. (1999) 9:699-702. doi: 10.1016/S0960-9822(99)80311-X

131. Gellert M. V(D)J recombination: RAG proteins, repair factors, and regulation. Annu Rev Biochem. (2002) 71:101-32. doi: 10.1146/annurev.biochem.71.090501.150203

132. Weterings E, van Gent DC. The mechanism of non-homologous end-joining: a synopsis of synapsis. DNA Repair. (2004) 3:1425-35. doi: 10.1016/j.dnarep.2004.06.003

133. Girard PM, Kysela B, Harer CJ, Doherty AJ, Jeggo PA. Analysis of DNA ligase IV mutations found in LIG4 syndrome patients: the impact of two linked polymorphisms. Hum Mol Genet. (2004) 13:2369-76. doi: 10.1093/hmg/ddh274

134. Staines Boone AT, Chinn IK, Alaez-Verson C, Yamazaki-Nakashimada MA, Carrillo-Sanchez K, Garcia-Cruz MLH, et al. Failing to make ends meet: the broad clinical spectrum of DNA ligase IV deficiency. case series and review of the literature. Front Pediatr. (2018) 6:426. doi: 10.3389/fped.2018. 00426

135. Altmann T, Gennery AR. DNA ligase IV syndrome; a review. Orphanet J Rare Dis. (2016) 11:137. doi: 10.1186/s13023-016-0520-1

136. Felgentreff K, Baxi SN, Lee YN, Dobbs K, Henderson LA, Csomos $\mathrm{K}$, et al. Ligase-4 deficiency causes distinctive immune abnormalities in asymptomatic individuals. J Clin Immunol. (2016) 36:341-53. doi: 10.1007/s10875-016-0266-5

137. Frank KM, Sekiguchi JM, Seidl KJ, Swat W, Rathbun GA, Cheng HL, et al. Late embryonic lethality and impaired V(D)J recombination in mice lacking DNA ligase IV. Nature. (1998) 396:173-7. doi: 10.1038/24172

138. O’Driscoll M, Cerosaletti KM, Girard PM, Dai Y, Stumm M, Kysela $B$, et al. DNA ligase IV mutations identified in patients exhibiting developmental delay and immunodeficiency. Mol Cell. (2001) 8:1175-85. doi: 10.1016/S1097-2765(01)00408-7

139. Bacon CM, Wilkinson SJ, Spickett GP, Barge D, Lucraft HH, Jackson G, et al. Epstein-Barr virus-independent diffuse large B-cell lymphoma in DNA ligase 4 deficiency. J Allergy Clin Immunol. (2013) 131:1237-9, 1239. e1. doi: 10.1016/j.jaci.2012.10.027

140. Toita N, Hatano N, Ono S, Yamada M, Kobayashi R, Kobayashi I, et al. Epstein-Barr virus-associated B-cell lymphoma in a patient with DNA ligase IV (LIG4) syndrome. Am J Med Genet A. (2007) 143A:742-45. doi: 10.1002/ajmg.a.31644

141. Zhang MY, Keel SB, Walsh T, Lee MK, Gulsuner S, Watts AC, et al. Genomic analysis of bone marrow failure and myelodysplastic syndromes reveals phenotypic and diagnostic complexity. Haematologica. (2015) 100:42-8. doi: 10.3324/haematol.2014.113456

142. Moshous D, Pannetier C, de Chasseval R, le Deist F, Cavazzana-Calvo M, Romana S, et al. Partial T and B lymphocyte immunodeficiency and predisposition to lymphoma in patients with hypomorphic 
mutations in Artemis. J Clin Invest. (2003) 111:381-7. doi: 10.1172/JCI1 6774

143. Kager L, Jimenez Heredia R, Hirschmugl T, Dmytrus J, Krolo A, Muller H, et al. Targeted mutation screening of 292 candidate genes in 38 children with inborn haematological cytopenias efficiently identifies novel diseasecausing mutations. Br J Haematol. (2018) 182:251-8. doi: 10.1111/bjh. 15389

144. Croteau DL, Popuri V, Opresko PL, Bohr VA. Human RecQ helicases in DNA repair, recombination, and replication. Annu Rev Biochem. (2014) 83:519-52. doi: 10.1146/annurev-biochem-060713-035428

145. Bloom D. Congenital telangiectatic erythema resembling lupus erythematosus in dwarfs; probably a syndrome entity. AMA Am J Dis Child. (1954) 88:754-8. doi: 10.1001/archpedi.1954.02050100756008

146. German J, Crippa LP, Bloom D. Bloom's syndrome. III Analysis of the chromosome aberration characteristic of this disorder. Chromosoma. (1974) 48:361-6. doi: 10.1007/BF00290993

147. Cunniff C, Djavid AR, Carrubba S, Cohen B, Ellis NA, Levy CF, et al. Health supervision for people with Bloom syndrome. Am J Med Genet A. (2018) 176:1872-81. doi: 10.1002/ajmg.a.40374

148. Flanagan M, Cunniff CM. Bloom syndrome. In: Adam MP, Ardinger HH, Pagon RA, Wallace SE, Bean LJH, Stephens K, Amemiya A, editors. GeneReviews((R)). Seattle, WA (1993).

149. Patel DS, Misenko SM, Her J, Bunting SF. BLM helicase regulates DNA repair by counteracting RAD51 loading at DNA double-strand break sites. J Cell Biol. (2017) 216:3521-34. doi: 10.1083/jcb.201703144

150. Cunniff C, Bassetti JA, Ellis NA. Bloom's syndrome: clinical spectrum, molecular pathogenesis, cancer predisposition. Mol Syndromol. (2017) 8:423. doi: $10.1159 / 000452082$

151. Diaz A, Vogiatzi MG, Sanz MM, German J. Evaluation of short stature, carbohydrate metabolism and other endocrinopathies in Bloom's syndrome. Horm Res. (2006) 66:111-7. doi: 10.1159/000093826

152. Masmoudi A, Marrakchi S, Kamoun H, Chaaben H, Ben Salah G, Ben Salah R, et al. Clinical and laboratory findings in 8 patients with Bloom's syndrome. J Dermatol Case Rep. (2012) 6:29-33. doi: 10.3315/jdcr.201 2.1086

153. Werner O. On cataract in conjunction with scleroderma. Otto Werner, doctoral dissertation, 1904 Royal ophthalmology clinic, royal christian albrecht University of Kiel. Adv Exp Med Biol. (1985) 190:1-14. doi: 10.1007/978-1-4684-7853-2_1

154. Oshima J, Sidorova JM, Monnat RJ Jr. Werner syndrome: clinical features, pathogenesis and potential therapeutic interventions. Ageing Res Rev. (2017) 33:105-14. doi: 10.1016/j.arr.2016.03.002

155. Oshima J, Martin GM, Hisama FM. Werner syndrome. In: Adam RA, Pagon MP, Bird TD, Dolan CR, Fong CT, Stephens K, editors. GeneReviews. Seattle, WA:GeneReviews (2014).

156. Satoh M, Imai M, Sugimoto M, Goto M, Furuichi Y. Prevalence of Werner's syndrome heterozygotes in Japan. Lancet. (1999) 353:1766. doi: 10.1016/S0140-6736(98)05869-3

157. Masala MV, Scapaticci S, Olivieri C, Pirodda C, Montesu MA, Cuccuru $\mathrm{MA}$, et al. Epidemiology and clinical aspects of Werner's syndrome in North Sardinia: description of a cluster. Eur J Dermatol. (2007) 17:213-6. doi: 10.1684/ejd.2007.0155

158. Oshima J, Huang S, Pae C, Campisi J, Schiestl RH. Lack of WRN results in extensive deletion at nonhomologous joining ends. Cancer Res. (2002) 62:547-51. Available online at: https://cancerres.aacrjournals.org/ content/62/2/547

159. Yu CE, Oshima J, Fu YH, Wijsman EM, Hisama F, Alisch R, et al. Positional cloning of the Werner's syndrome gene. Science. (1996) 272:25862. doi: 10.1126/science.272.5259.258

160. Sturzenegger A, Burdova K, Kanagaraj R, Levikova M, Pinto C, Cejka P, et al. DNA2 cooperates with the WRN and BLM RecQ helicases to mediate longrange DNA end resection in human cells. J Biol Chem. (2014) 289:27314-26. doi: $10.1074 /$ jbc.M114.578823

161. Sidorova JM. Roles of the Werner syndrome RecQ helicase in DNA replication. DNA Repair. (2008) 7:1776-86. doi: 10.1016/j.dnarep.2008.07.017

162. Edwards DN, Orren DK, Machwe A. Strand exchange of telomeric DNA catalyzed by the Werner syndrome protein (WRN) is specifically stimulated by TRF2. Nucleic Acids Res. (2014) 42:7748-61. doi: 10.1093/nar/gku454
163. Takemoto M, Mori S, Kuzuya M, Yoshimoto S, Shimamoto A, Igarashi $\mathrm{M}$, et al. Diagnostic criteria for Werner syndrome based on Japanese nationwide epidemiological survey. Geriatr Gerontol Int. (2013) 13:475-81. doi: 10.1111/j.1447-0594.2012.00913.x

164. Huang S, Lee L, Hanson NB, Lenaerts C, Hoehn H, Poot M, et al. The spectrum of WRN mutations in Werner syndrome patients. Hum Mutat. (2006) 27:558-67. doi: 10.1002/humu.20337

165. Martin GM, Oshima J, Gray MD, Poot M. What geriatricians should know about the Werner syndrome. J Am Geriatr Soc. (1999) 47:1136-44. doi: 10.1111/j.1532-5415.1999.tb05240.x

166. Goto M, Miller RW, Ishikawa Y, Sugano H. Excess of rare cancers in Werner syndrome (adult progeria). Cancer Epidemiol Biomarkers Prev. (1996) 5:23946.

167. Lauper JM, Krause A, Vaughan TL, Monnat RJ Jr. Spectrum and risk of neoplasia in Werner syndrome: a systematic review. PLoS ONE. (2013) 8:e59709. doi: 10.1371/journal.pone.0059709

168. Chen L, Lee L, Kudlow BA, Dos Santos HG, Sletvold O, Shafeghati Y, et al. LMNA mutations in atypical Werner's syndrome. Lancet. (2003) 362:440-5. doi: 10.1016/S0140-6736(03)14069-X

169. Lessel D, Hisama FM, Szakszon K, Saha B, Sanjuanelo AB, Salbert BA, et al. POLD1 Germline mutations in patients initially diagnosed with Werner syndrome. Hum Mutat. (2015) 36:1070-9. doi: 10.1002/humu.22833

170. Wang LL, Plon SE. Rothmund-thomson syndrome. In: Adam MP, Ardinger HH, Pagon RA, Wallace SE, Bean LJH, Stephens K, Amemiya A, editors. GeneReviews((R)). Seattle, WA: GeneReviews (1993).

171. Lu H, Shamanna RA, Keijzers G, Anand R, Rasmussen LJ, Cejka P, et al. RECQL4 promotes DNA end resection in repair of DNA double-strand breaks. Cell Rep. (2016) 16:161-73. doi: 10.1016/j.celrep.2016.05.079

172. Lu H, Shamanna RA, Freitas JK, Okur M, Khadka P, Kulikowicz T, et al. Cell cycle-dependent phosphorylation regulates RECQL4 pathway choice and ubiquitination in DNA double-strand break repair. Nat Commun. (2017) 8:2039-52. doi: 10.1038/s41467-017-02146-3

173. Larizza L, Roversi G, Volpi L. Rothmund-Thomson syndrome. Orphanet $J$ Rare Dis. (2010) 5:2. doi: 10.1186/1750-1172-5-2

174. Mehollin-Ray AR, Kozinetz CA, Schlesinger AE, Guillerman RP, Wang LL. Radiographic abnormalities in Rothmund-Thomson syndrome and genotype-phenotype correlation with RECQL4 mutation status. AJR Am J Roentgenol. (2008) 191:W62-6. doi: 10.2214/AJR.07.3619

175. Dollfus H, Porto F, Caussade P, Speeg-Schatz C, Sahel J, Grosshans E, et al. Ocular manifestations in the inherited DNA repair disorders. Surv Ophthalmol. (2003) 48:107-22. doi: 10.1016/S0039-6257(02)00400-9

176. Haytac MC, Oztunc H, Mete UO, Kaya M. Rothmund-Thomson syndrome: a case report. Oral Surg Oral Med Oral Pathol Oral Radiol Endod. (2002) 94:479-84. doi: 10.1067/moe.2002.127584

177. Wang LL, Levy ML, Lewis RA, Chintagumpala MM, Lev D, Rogers $\mathrm{M}$, et al. Clinical manifestations in a cohort of 41 RothmundThomson syndrome patients. Am J Med Genet. (2001) 102:11-7. doi: 10.1002/1096-8628(20010722)102:1<11::AID-AJMG1413>3.0.CO;2-A

178. Broom MA, Wang LL, Otta SK, Knutsen AP, Siegfried E, Batanian JR, et al. Successful umbilical cord blood stem cell transplantation in a patient with Rothmund-Thomson syndrome and combined immunodeficiency. Clin Genet. (2006) 69:337-43. doi: 10.1111/j.1399-0004.2006.0 0592.x

179. de Somer L, Wouters C, Morren MA, de Vos R, van Den Oord J, Devriendt K, et al. (2010). Granulomatous skin lesions complicating Varicella infection in a patient with Rothmund-Thomson syndrome and immune deficiency: case report. Orphanet J Rare Dis. 5:37. doi: 10.1186/1750-11 72-5-37

180. Ito T, Tokura Y, Moriwaki S, Yasuda K, Ohnishi A, Furukawa F, et al. Rothmund-Thomson syndrome with herpes encephalitis. Eur J Dermatol. (1999) 9:354-6.

181. Borg MF, Olver IN, Hill MP. Rothmund-Thomson syndrome and tolerance of chemoradiotherapy. Aust Radiol. (1998) 42:216-8. doi: 10.1111/j.1440-1673.1998.tb00496.x

182. Howell SM, Bray DW. Amelanotic melanoma in a patient with Rothmund-Thomson syndrome. Arch Dermatol. (2008) 144:416-7. doi: 10.1001/archderm.144.3.416

183. Kaariainen H, Ryoppy S, Norio R. RAPADILINO syndrome with radial and patellar aplasia/hypoplasia as main manifestations. 
Am J Med Genet. (1989) 33:346-51. doi: 10.1002/ajmg.132033 0312

184. Siitonen HA, Kopra O, Kaariainen H, Haravuori H, Winter RM, Saamanen $\mathrm{AM}$, et al. Molecular defect of RAPADILINO syndrome expands the phenotype spectrum of RECQL diseases. Hum Mol Genet. (2003) 12:283744. doi: $10.1093 / \mathrm{hmg} / \mathrm{ddg} 306$

185. Siitonen HA, Sotkasiira J, Biervliet M, Benmansour A, Capri Y, CormierDaire V, et al. The mutation spectrum in RECQL4 diseases. Eur J Hum Genet. (2009) 17:151-8. doi: 10.1038/ejhg.2008.154

186. Cohen MM Jr. An etiologic and nosologic overview of craniosynostosis syndromes. Birth Defects Orig Artic Ser. (1975) 11:137-89.

187. Kaneko H, Izumi R, Oda H, Ohara O, Sameshima K, Ohnishi H, et al. Nationwide survey of BallerGerold syndrome in Japanese population. Mol Med Rep. (2017) 15:3222-4. doi: 10.3892/mmr.2017.6408

188. Megarbane A, Melki I, Souraty N, Gerbaka J, El Ghouzzi V, Bonaventure J, et al. Overlap between Baller-Gerold and Rothmund-Thomson syndrome. Clin Dysmorphol. (2000) 9:303-5. doi: 10.1097/00019605-200009040-00018

189. Debeljak M, Zver A, Jazbec J. A patient with Baller-Gerold syndrome and midline NK/T lymphoma. Am J Med Genet A. (2009) 149A:755-9. doi: 10.1002/ajmg.a.32736

190. Riley BD, Culver JO, Skrzynia C, Senter LA, Peters JA, Costalas JW, et al. Essential elements of genetic cancer risk assessment, counseling, and testing: updated recommendations of the National society of genetic counselors. $J$ Genet Couns. (2012) 21:151-61. doi: 10.1007/s10897-011-9462-x

191. Giardiello FM, Allen JI, Axilbund JE, Boland CR, Burke CA, Burt RW, et al. Guidelines on genetic evaluation and management of Lynch syndrome: a consensus statement by the US multi-society task force on colorectal cancer. Am J Gastroenterol. (2014) 109:1159-79. doi: 10.1038/ajg.2014.186

192. National Comprehensive Cancer Network (NCCN). Genetic/Familial HighRisk Assessment: Colorectal (Version 3.2019) (2019). Available online at: https://www.nccn.org/professionals/physician_gls/pdf/genetics_colon.pdf (accessed May 14, 2020).

193. National Comprehensive Cancer Network (NCCN). Genetic/Familial HighRisk Assessment: Breast, Ovarian, and Pancreatic. Version 1.2020 (2020). Available online at: https://www.nccn.org/professionals/physician_gls/pdf/ genetics_bop.pdf (accessed May 14, 2020).

194. Forbes C, Fayter D, de Kock S, Quek RG. A systematic review of international guidelines and recommendations for the genetic screening, diagnosis, genetic counseling, and treatment of BRCA-mutated breast cancer. Cancer Manag Res. (2019) 11:2321-37. doi: 10.2147/CMAR.S189627

195. Crosbie EJ, Ryan NAJ, Arends MJ, Bosse T, Burn J, Cornes JM, et al. The Manchester International consensus group recommendations for the management of gynecological cancers in Lynch syndrome. Genet Med. (2019) 21:2390-400. doi: 10.1038/s41436-019-0489-y

196. Frebourg T, Bajalica Lagercrantz S, Oliveira C, Magenheim R, Evans DG, European Reference Network Group. Guidelines for the Li-Fraumeni and heritable TP53-related cancer syndromes. Eur J Hum Genet. (2020) 28:137686. doi: 10.1038/s41431-020-0638-4

197. Ryan NAJ, Morris J, Green K, Lalloo F, Woodward ER, Hill J, et al. Association of mismatch repair mutation with age at cancer onset in lynch syndrome: implications for stratified surveillance strategies. JAMA Oncol. (2017) 3:1702-6. doi: 10.1001/jamaoncol.2017.0619

198. Ten Broeke SW, van der Klift HM, Tops CMJ, Aretz S, Bernstein I, Buchanan DD, et al. (2018). Cancer risks for PMS2-associated lynch syndrome. J Clin Oncol. 36:2961-8. doi: 10.1200/JCO.2018.7 8.4777

199. Mavaddat N, Peock S, Frost D, Ellis S, Platte R, Fineberg E, et al. Cancer risks for BRCA1 and BRCA2 mutation carriers: results from prospective analysis of EMBRACE. J Natl Cancer Inst. (2013) 105:812-22. doi: 10.1093/jnci/d jt095

200. Petrucelli N, Daly MB, Pal T. BRCA1- and BRCA2-associated hereditary breast and ovarian cancer. In: Adam MP, Ardinger HH, Pagon RA, Wallace SE, Bean LJH, Stephens K, Amemiya A, editors. GeneReviews((R)) Seattle, WA: GeneReviews (1993).

201. Weber-Lassalle N, Hauke J, Ramser J, Richters L, Gross E, Blumcke B, et al. (2018). BRIP1 loss-of-function mutations confer high risk for familial ovarian cancer, but not familial breast cancer. Breast Cancer Res. 20:7. doi: 10.1186/s13058-018-0935-9
202. Marabelli M, Cheng SC, Parmigiani G. Penetrance of ATM gene mutations in breast cancer: a meta-analysis of different measures of risk. Genet Epidemiol. (2016) 40:425-31. doi: 10.1002/gepi.21971

203. Hu C, Hart SN, Polley EC, Gnanaolivu R, Shimelis H, Lee KY, et al. Association between inherited germline mutations in cancer predisposition genes and risk of pancreatic cancer. JAMA. (2018) 319:24019. doi: $10.1001 /$ jama.2018.6228

204. Rusak B, Kluzniak W, Wokolorczyk D, Stempa K, Kashyap A, Rudnicka $\mathrm{H}$, et al. Allelic modification of breast cancer risk in women with an NBN mutation. Breast Cancer Res Treat. (2019) 178:427-31. doi: 10.1007/s10549-019-05391-w

205. Rusak B, Kluzniak W, Wokolorczykv D, Stempa K, Kashyap A, Gronwald J, et al. Inherited NBN mutations and prostate cancer risk and survival. Cancer Res Treat. (2019) 51:1180-7. doi: 10.4143/crt.2018.532

206. Savage SA. Dyskeratosis congenita. In: Adam MP, Ardinger HH, Pagon RA, Wallace SE, Bean LJH, Stephens K, Amemiya A, editors. GeneReviews $((R))$. Seattle, WA: GeneReviews (1993).

207. Leteurtre F, Li X, Guardiola P, Le Roux G, Sergere JC, Richard P, et al. Accelerated telomere shortening and telomerase activation in Fanconi's anaemia. Br J Haematol. 105:883-93. doi: 10.1046/j.1365-2141.1999.01445.x

208. Adelfalk C, Lorenz M, Serra V, von Zglinicki T, Hirsch-Kauffmann M, Schweiger M. Accelerated telomere shortening in Fanconi anemia fibroblasts-a longitudinal study. FEBS Lett. (2001) 506:22-6. doi: 10.1016/S0014-5793(01)02869-1

209. Pandita TK, Pathak S, Geard CR. Chromosome end associations, telomeres and telomerase activity in ataxia telangiectasia cells. Cytogenet Cell Genet. (1995) 71:86-93. doi: 10.1159/000134069

210. Kishi S, Lu KP. A critical role for Pin2/TRF1 in ATM-dependent regulation. Inhibition of Pin2/TRF1 function complements telomere shortening, radiosensitivity, and the $\mathrm{G}(2) / \mathrm{M}$ checkpoint defect of ataxia-telangiectasia cells. J Biol Chem. (2002) 277:7420-9. doi: 10.1074/jbc.M111365200

211. Bai Y, Murnane JP. Telomere instability in a human tumor cell line expressing NBS1 with mutations at sites phosphorylated by ATM. Mol Cancer Res. (2003) 1:1058-69. Available online at: https://mcr.aacrjournals. org/content/1/14/1058

212. Mendez-Bermudez A, Hidalgo-Bravo A, Cotton VE, Gravani A, Jeyapalan JN, Royle NJ. The roles of WRN and BLM RecQ helicases in the alternative lengthening of telomeres. Nucleic Acids Res. (2012) 40:10809-20. doi: $10.1093 / \mathrm{nar} / \mathrm{gks} 862$

213. Crabbe L, Verdun RE, Haggblom CI, Karlseder J. Defective telomere lagging strand synthesis in cells lacking WRN helicase activity. Science. (2004) 306:1951-3. doi: 10.1126/science.1103619

214. Nourizadeh M, Shakerian L, Borte S, Fazlollahi M, Badalzadeh M, Houshmand $\mathrm{M}$, et al. Newborn screening using TREC/KREC assay for severe $\mathrm{T}$ and B cell lymphopenia in Iran. Scand J Immunol. (2018) 88:e12699. doi: $10.1111 /$ sji. 12699

215. Wolska-Kusnierz B, Gennery AR. Hematopoietic stem cell transplantation for DNA double strand breakage repair disorders. Front Pediatr. (2019) 7:557. doi: 10.3389/fped.2019.00557

216. van der Burgt I, Chrzanowska KH, Smeets D, Weemaes C. Nijmegen breakage syndrome. J Med Genet. (1996) 33:153-6. doi: 10.1136/jmg. 33.2.153

217. Aurias A, Dutrillaux B, Buriot D, Lejeune J. High frequencies of inversions and translocations of chromosomes 7 and 14 in ataxia telangiectasia. Mutat Res. (1980) 69:369-74. doi: 10.1016/0027-5107(80)90101-3

218. Waldmann TA, McIntire KR. Serum-alpha-fetoprotein levels in patients with ataxia-telangiectasia. Lancet. (1972) 2:1112-5. doi: 10.1016/S0140-6736(72)92717-1

219. Cassinat B, Guardiola P, Chevret S, Schlageter MH, Toubert ME, Rain JD, et al. Constitutive elevation of serum alpha-fetoprotein in Fanconi anemia. Blood. (2000) 96:859-63. doi: 10.1182/blood.V96.3.859

220. Kraemer KH, DiGiovanna JJ. Xeroderma pigmentosum. In: Adam MP, Ardinger HH, Pagon RA, Wallace SE, Bean LJH, Stephens K, Amemiya A, editors. GeneReviews((R)). Seattle, WA: GeneReviews (1993).

221. Gomolka M, Blyth B, Bourguignon M, Badie C, Schmitz A, Talbot C, et al. Potential screening assays for individual radiation sensitivity and susceptibility and their current validation state. Int J Radiat Biol. (2020) 96:280-96. doi: 10.1080/09553002.2019.1642544 
222. Buchbinder D, Smith MJ, Kawahara M, Cowan MJ, Buzby JS, Abraham RS. Application of a radiosensitivity flow assay in a patient with DNA ligase 4 deficiency. Blood Adv. (2018) 2:1828-32. doi: 10.1182/bloodadvances.2018016113

223. Feurstein S, Drazer MW, Godley LA. Genetic predisposition to leukemia and other hematologic malignancies. Semin Oncol. (2016) 43:598-608. doi: 10.1053/j.seminoncol.2016.10.003

224. Hayward BE, de Vos M, Valleley EM, Charlton RS, Taylor GR, Sheridan E, et al. Extensive gene conversion at the PMS2 DNA mismatch repair locus. Hum Mutat. (2007) 28:424-30. doi: 10.1002/humu.20457

225. Richards S, Aziz N, Bale S, Bick D, Das S, Gastier-Foster J, et al. Standards and guidelines for the interpretation of sequence variants: a joint consensus recommendation of the American college of medical genetics and genomics and the association for molecular pathology. Genet Med. (2015) 17:405-24. doi: $10.1038 /$ gim. 2015.30
226. Nickoloff JA, Jones D, Lee SH, Williamson EA, Hromas R. Drugging the cancers addicted to DNA repair. J Natl Cancer Inst. (2017) 109:djx059. doi: 10.1093/jnci/djx059

Conflict of Interest: The authors declare that the research was conducted in the absence of any commercial or financial relationships that could be construed as a potential conflict of interest.

Copyright (c) 2020 Sharma, Lewis and Wlodarski. This is an open-access article distributed under the terms of the Creative Commons Attribution License (CC BY). The use, distribution or reproduction in other forums is permitted, provided the original author(s) and the copyright owner(s) are credited and that the original publication in this journal is cited, in accordance with accepted academic practice. No use, distribution or reproduction is permitted which does not comply with these terms. 